IZA DP No. 10361

How Does Pension Eligibility Affect Labor Supply in Couples?

Rafael Lalive

Pierpaolo Parrotta

November 2016 


\title{
How Does Pension Eligibility Affect Labor Supply in Couples?
}

\author{
Rafael Lalive \\ University of Lausanne, \\ CEPR, CESifo and IZA \\ Pierpaolo Parrotta \\ ICN Business School \\ and IZA
}

\section{Discussion Paper No. 10361 \\ November 2016}

\author{
IZA \\ P.O. Box 7240 \\ 53072 Bonn \\ Germany \\ Phone: +49-228-3894-0 \\ Fax: +49-228-3894-180 \\ E-mail: iza@iza.org
}

\begin{abstract}
Any opinions expressed here are those of the author(s) and not those of IZA. Research published in this series may include views on policy, but the institute itself takes no institutional policy positions. The IZA research network is committed to the IZA Guiding Principles of Research Integrity.

The Institute for the Study of Labor (IZA) in Bonn is a local and virtual international research center and a place of communication between science, politics and business. IZA is an independent nonprofit organization supported by Deutsche Post Foundation. The center is associated with the University of Bonn and offers a stimulating research environment through its international network, workshops and conferences, data service, project support, research visits and doctoral program. IZA engages in (i) original and internationally competitive research in all fields of labor economics, (ii) development of policy concepts, and (iii) dissemination of research results and concepts to the interested public.
\end{abstract}

IZA Discussion Papers often represent preliminary work and are circulated to encourage discussion. Citation of such a paper should account for its provisional character. A revised version may be available directly from the author. 


\begin{abstract}
How Does Pension Eligibility Affect Labor Supply in Couples?

Many OECD countries are reforming their pension systems. We investigate how pension eligibility affects labor supply in couples. Inspired by a theoretical framework, we measure how the sharp change in the pension eligibility of both partners affects labor force participation. We find that both partners leave the labor force as they become eligible for a pension. The effect of their own pension eligibility is 12 percentage points for women and 28 percentage points for men. Women also reduce their labor force participation by 2 to 3 percentage points as their partner reaches pension eligibility. For men, the effect of their partner's eligibility is smaller and not significantly different from zero. For women and men with low education, the effect of their own eligibility is strong. Regardless of education level, the partner eligibility effect is strong in homogamous couples. Studying joint labor supply, we find that pension eligibility reduces labor supply in couples by 44 percentage points, approximately 4 percentage points more than in a model that ignores partner eligibility effects.
\end{abstract}

JEL Classification: J26, J14, C40, D10

Keywords: couple labor supply, pension eligibility, full retirement age, household decisions

Corresponding author:

Rafael Lalive

Department of Economics

University of Lausanne

$\mathrm{CH}-1015$ Lausanne

Switzerland

E-mail: Rafael.Lalive@unil.ch

\footnotetext{
${ }^{*}$ We appreciated helpful comments by two referees and the associate editor, Andrea Weber. We have presented an earlier version of the paper to seminar audiences at Universities of Lausanne and Lucerne. Rafael Lalive and Pierpaolo Parrotta gratefully acknowledge the financial support from Swiss NCCR LIVES. Pierpaolo Parrotta also acknowledges the financial support from the Carlsberg Foundation. The usual disclaimer applies.
} 


\section{Introduction}

OECD countries are experiencing sweeping changes: an aging population, dropping fertility rates, an increasing female labor supply and improving living conditions. Each of these factors has contributed to moving the sustainability of the social security and pension system to one of the top priorities of public policy. Thus, the increasing dependency ratio - the ratio of retirees to workers - has pushed national authorities to reform their social security legislation; in several cases, this has mainly resulted in an increase in the full retirement age (FRA).

How raising the FRA translates into an increase in the actual retirement age is an active area of current research. However, studies tend to neglect the effects on pension eligibility of one spouse on the other. These effects could potentially be large; several studies suggest that retirement is likely to be a joint decision of both partners in a couple. Workers approaching retirement age are typically married or have been living with a partner for a long time, and dual-career couples are common among older cohorts. Investigating couples' joint retirement choices can help in evaluating or predicting the effects produced by reforms in pension schemes.

The key challenge to identifying pension eligibility effects is that retirement decisions are jointly planned, and they can be driven by shared tastes for leisure or other typically unobserved determinants of labor supply. Correlating labor force participation across spouses in a couple does not provide a meaningful assessment of joint labor supply.

We analyze couple labor supply decisions triggered by sharp changes in pension eligibility associated with age. Specifically, we analyze the joint retirement decisions of spouses around the age of full retirement in Switzerland. We address the question in two steps. First, we build a simple static model of labor supply decisions. The model assumes that two partners in a couple have identical preferences with respect to consumption. Partner members differ in terms of the weight they attach to one another's leisure. We also assume that all consumption goods are shared between the two partners in a couple. This simple framework introduces two mechanisms for the pension incentives of one partner to affect the other partner: leisure complementarities and interactions via the household budget constraint. Second, we build an empirical strategy inspired by the model. Our estimation strategy is a specification that captures the discontinuous change in pension eligibility with respect to age of both partners, a so-called double regression discontinuity design (D-RDD). This approach identifies the effects of individuals' own eligibility and their partner's pension eligibility effects using standard RDD logic. For instance, the partner eligibility effect is identified by contrasting members of a partner eligible (PE) group, whose partner has just reached the FRA, to those of the partner 
ineligible (PI) group, whose partner has not yet reached the FRA. If partner eligibility to a pension matters, the PE group will be less likely to work than the PI group.

We use data from the Swiss Federal Population Census database covering the years 1990 and 2000. Census data provide information on cohabitating or married individuals, including their age, education, mother tongue, labor market participation, religion, and place of residence. These data are well suited for analyzing joint retirement because they provide information on several hundred thousand couples in the age bracket of 15 years prior to and 15 years after full retirement. Switzerland is also an interesting case study because pension eligibility rules trigger a sharp reduction in labor supply around the full age of retirement (62 years for women, 65 years for men). The empirical analysis relies on these sharp changes in labor supply to identify partner eligibility effects.

Our results indicate that individuals' own eligibility matters. Women are 12 percentage points less likely to be in the labor force once they reach the FRA; the effect for men is 28 percentage points. We also find evidence that partner pension eligibility matters for labor force exit. A woman whose partner obtains access to an old-age pension is 2.3 percentage points less likely to be in the labor force. The partner eligibility effect is not significant for men.

The effect of individuals' own eligibility is largest for women and men who have attained at most a lower secondary education. This is in line with financial incentives, as the pension replacement rate is largest for this education group. The partner eligibility effect is strongest in couples that are homogamous with respect to education, regardless of its level.

Do partner eligibility effects matter for couple labor supply? To illustrate the consequences, we build an empirical model that takes into account the effects of both individuals' own eligibility and their partner's eligibility. This model suggests that couple labor supply drops by 31 percentage points as the husband reaches the FRA. A model that focuses on the husband alone predicts a reduction in labor force participation of 28 percentage points. The couple labor supply model predicts that couple labor supply decreases by 13.5 percentage points as the wife reaches the FRA. Modeling the wife's labor supply indicates a reduction in labor supply of 12.5 percentage points.

What do these estimates mean for policy? We estimate labor supply effects in the context of the standard RDD. In our context, the RDD provides an estimate of the causal effect of increasing the FRA by a small amount, e.g., one year. Our couple labor supply results indicate that increasing the FRA for both women and men by one year will increase couple labor force participation by slightly more than 44 percent. A model that ignores couple labor supply would predict an increase of slightly less than 41 percent. The effect of raising the FRA is almost 10 percent larger in our joint model than 
models ignoring partner eligibility effects would indicate.

The existing literature has studied retirement choices and how they can be explained using individual demographic characteristics, health condition, insurance, wealth status, labor market experience and social security benefits. ${ }^{1}$ However, these analyses typically neglect potential within household interactions: the decision making of a family is represented by a joint utility function for all household members. Instead, there is no room for cross-spouse interactions in individual retirement decisions.

The literature started focusing on spouses' joint labor supply behavior with the growth of the proportion of married women having substantial work experience and approaching retirement age. This line of research investigating the behavior of couples at the eve of retirement emerges with Hurd (1990). Using the New Beneficiary Survey (NBS) for the period June 1980 - May 1981, he provides evidence on the tendency for wives and husbands to retire together. Hurd states clearly that the causality of such behavior can be imputed to the structure of financial incentives, similarity in tastes and complementarity of leisure.

Using the Retirement History Survey (RHS) from 1969 to 1979, Blau (1998) estimates a structural model and finds strong associations between one spouse's labor market participation and the labor force transitions of the other spouse. Blau argues that financial incentives are not the main determinants that explain the simultaneity in participation decisions. Instead, it seems more plausible that it is a result of "preferences for shared leisure." However, the main limitation of Blau's work is related to the lack of precision in the estimates due to the high degree of complexity of his dynamic multinomial probit model.

An interesting extension of Blau's approach is provided by Michaud (2003). He implements a bivariate dynamic binary choice model with serially correlated errors and unobserved heterogeneity. In particular, using an updated version of RHS and imposing plausible restrictions on Blau's approach to reduce the computational complexities, he provides evidence of cross-spouse state dependence that "points to indirect effects of social security and pension incentives through complementarity in leisure."

Similar conclusions are drawn by works employing a reduced form approach, such as Zweimüller et al. (1996). ${ }^{2}$ Zweimüller et al. (1996) study interdependent retirement in Austria (Austrian Mikrozensus 1983), finding complementarity and asymmetries between couples' labor supply decisions: husbands react to changes in their wives' legal retirement age but not vice versa (Zweimüller et al.,

\footnotetext{
${ }^{1}$ Gustman and Steinmeier (1986); Burtless (1986); Stock and Wise (1990); Rust and Phelan (1997); French (2005), among others. Blau and Gilleskie (2006) and Van der Klaauw and Wolpin (2008) study retirement allowing for couple interactions.

${ }^{2}$ The reduced form approach is also implemented by Baker (2002), Coile (2004), and An et al. (2004). All find evidence of the complementarity of leisure between partners.
} 
1996).

A number of papers have also estimated structural bargaining models of couples' retirement behavior. A cooperative game approach is implemented in Michaud and Vermeulen (2004), ${ }^{3}$ and a non-cooperative one is employed in Gustman and Steinmeier (2000, 2004, 2005, 2009). Despite the distinctions between the two theoretical approaches, these studies find that leisure complementarities are crucial to explain coordination in spouses' retirement choices.

Two papers are closely related to ours. Stancanelli and van Soest (2012a,b) adopt a regression discontinuity approach similar to ours to identify the effects of partners' retirement on home production or joint leisure using detailed time diary data on approximately 1000 French couples before and after retirement. Stancanelli and van Soest (2012a) do not find an effect of partners' eligibility for retirement on individuals' own retirement or market hours. Stancanelli and van Soest (2012b) find that the female partner's retirement increases the hours of joint leisure. There is no corresponding effect for the man's retirement on joint leisure.

This paper complements the existing literature in the following aspects. First, as Stancanelli and van Soest $(2012 \mathrm{a}, \mathrm{b})$ do, we rely on a transparent quasi-experimental design to identify the effects of individuals' own eligibility and their partner's eligibility. The RDD approach addresses the key issues that have plagued studies aiming to learn about interactions from joint labor supply decisions. Second, we use a simple theoretical framework to develop our key empirical specification and show how it is linked to the double regression discontinuity design, pioneered by Stancanelli and van Soest (2012a,b). Third, we focus on understanding pension eligibility effects rather than actual retirement decisions. Studying pension eligibility, perhaps a more modest endeavor, is more credible and policy relevant than studying actual retirement decisions. Pension eligibility effects are policy relevant as they provide the effects of changing access to retirement benefits - for instance, raising the FRA. Fourth, we document the policy implications of policy spillovers by proposing a model of couple labor supply. This model highlights that couple labor supply effects cannot just be derived from individual labor supply effects.

The remainder of the paper is structured as follows. Section 2 discusses the institutional background. Section 3 outlines a simple model of couple labor supply. Section 4 introduces the data set and provides descriptive evidence and statistics on the sub-sample of older workers. Section 5 develops our empirical strategy. Section 6 presents our results on the role of pension eligibility in labor supply among couples. Section 7 concludes.

\footnotetext{
${ }^{3}$ Maestas (2001), Jia (2005), Mastrogiacomo et al. (2002), van der Klaauw and Wolpin (2008), Casanova Rivas (2010), and Honor and de Paula (2010) are also based on cooperative games.
} 


\section{Background}

This section provides background information on the Swiss pension system. The Swiss pension system has three pillars. The first pillar, public old-age insurance, was introduced in 1947 to provide income to cover basic needs in old age. This pillar is financed by contributions of approximately $8 \%$ of every employee's wage, and benefits are paid to recipients of old-age pensions from the old-age insurance fund, a pay-as-you-go system. The first pillar aims at covering basic living expenses, so the yearly pension is capped at approximately one half of the median income.

Individuals can draw a full pension only when they have reached the full retirement age (FRA). In the period of our study, women can claim retirement benefits at 62 years, whereas men can do so at 65 years. Individuals cannot draw pension benefits before the FRA but can defer claiming benefits for up to five years after the full age at actuarially fair adjustments. Pension benefits depend on the prior work history - 42 years for women and 45 years for men -and on the insured earnings of the claimant. In 1994, pension benefits ranged from 11,280 CHF for insured earnings of 11,280 CHF and below (a replacement rate of 1 or higher) to 22,560 CHF per year for insured earnings of 68,000 CHF and above (a replacement rate of $33 \%$ or lower). Individuals can work and claim at the same time, and there is no earnings test.

Special rules are in place concerning retirement of spouses. In the case that a man claims a pension before his spouse does, he is eligible for the single pension based on his labor market history. Equivalently, in the case that a woman claims a pension before her husband does, she is eligible for a single pension based on her labor market history. Couples become eligible to a joint pension of at most $150 \%$ of the individual pension to which the husband is eligible once husband and wife reach the full pension age. ${ }^{4}$

The second pillar, created in 1985, consists of a multitude of occupational benefit plans aimed to provide retired workers with an appropriate income to guarantee the accustomed (pre-retirement) standards of living. The second pillar is private, regulated by the federal government. Federal law requires employers to contribute at least as much as employees do: there is a large degree of flexibility because contribution rates are proposed by pension funds. Early claiming of the second pillar benefits is possible, up to five years before the full age. Earnings below a minimum threshold are not subject to second pillar contributions. Many women in the cohorts of our sample do not have a second pillar pension.

\footnotetext{
${ }^{4}$ A 1997 reform introduced the possibility for men to claim early retirement at an actuarially fair rate. The reform also introduced the splitting of careers to assess the pensions of married couples, leading to a small but negligible improvement (1 to $3 \%$ ) of the pensions for married couples (Koller, 1998).
} 
The third pillar, the individual occupation pension scheme, is voluntary and supplements the state pension with sufficient means to ensure an ultimately comfortable retirement. The contribution rate is decided individually.

Old-age pension replacement rates are fairly high compared to other OECD countries (OECD, 2011). The first and second pillars together pay out approximately two thirds of pre-retirement earnings to the average wage earner, with both pillars contributing approximately the same amount. The net replacement rate is substantially lower for high earners. For instance, individuals earning twice the average wage see one third of their pre-retirement earnings replaced. High earners rely heavily on the third pillar to guarantee adequate income replacement. Women's pension levels are substantially lower than men's, primarily because of the high prevalence of part-time work among them.

Our empirical strategy focuses on changes in labor supply as women and men reach the FRA. In theory, there are no sharp changes in financial incentives to induce people to claim pensions or leave the labor force. However, in practice, pension claiming and labor force withdrawal may coincide with the FRA for several reasons. First, the default claiming age for the first pillar is the FRA. Individuals who do not actively opt out of claiming at the FRA will start their pension at the FRA. Second, some industries, e.g., the public sector, terminate labor contracts at the FRA. Individuals who want to continue working need to look for a new job at the FRA, which is not a simple task. Third, the FRA may act as a normal retirement age, coordinating people's actions (Behaghel and Blau, 2012), or people might want to leave the labor force before the FRA but be liquidity constrained. Assessing which of these reasons explains why people leave the labor force at the FRA, while interesting, is challenging. Our objective is to assess whether claiming at the FRA happens and whether individuals' partner's eligibility affects their own labor supply.

\section{Conceptual Framework}

We develop a simple static model of retirement decisions in a household context. Our objective is to illustrate the two key behavioral mechanisms that could lead to coordination in retirement of spouses. We keep the model deliberately simple in order to derive our reduced form specification of the model of retirement decisions.

Suppose each spouse in a household has the following utility function over household consumption $C$ and individual leisure $L_{i}$ (years of retirement): 


$$
U_{i}=C+\left[\frac{1}{2} L_{i}^{\lambda}+\frac{1}{2} L_{j}^{\frac{\lambda}{\theta_{i}}}\right]^{\frac{1}{\lambda}}
$$

where $i$ refers either to the wife, $F$, or to the husband, $M, C$ is household consumption $C \equiv C_{i}+C_{j}$, $L_{i}$ is $i$ 's leisure, $L_{j}$ is partner's leisure, $0<\theta_{i}$ is the $i$ 's (dis-)taste for her/his spouse's leisure, and $\lambda$ is the elasticity of substitution between consumption and leisure.

This framework builds one first key element that might matter in retirement choices, $\theta_{i}$. The magnitude of $\theta_{i}$ defines how important partner $i$ thinks partner $j$ 's leisure is for household well-being. Consider the case of $\theta_{i}$ approaching infinity. This is equivalent to stating partner $j$ 's leisure does not count in household well-being from the point of view of partner $i$. The opposite polar case is $\theta_{i}$ approaching 0 . In that case, the other partner's leisure is the only important type of leisure for household well-being. The case $\theta_{i}=1$, is the neutral case, both spouse's leisure are equally important for the household.

There are two key approaches to household decision making (Chiappori, 1988). The unitary approach pretends the household consists of just one individual. The non-cooperative approach assumes each partner in the couple individually. Our approach is a hybrid between the two. We assume that each spouse independently maximizes the utility function (1) above by choosing not only her or his years of leisure but also that of his or her spouse. In that sense, our solution follows the unitary approach. But by assuming that both partners do that, we are closer to the bargaining approach.

Spouse $M$ 's age at marriage is $a_{M}$, spouse $F$ 's age at marriage is $a_{F}$. Both spouses live for $T$ periods, so life-time hours of work are $h_{i} \equiv T-l_{i}$. The life-time budget constraint is:

$$
C \leq w_{M} h_{M}+w_{M} \rho\left(h_{M}+a_{M}\right)\left(T-h_{M}\right)+w_{F} h_{F}+w_{F} \rho\left(h_{F}+a_{F}\right)\left(T-h_{F}\right)+A
$$

where $\rho(h+a)$ is the pension replacement rate, i.e. the ratio of pension income to the income that could be earned by working, available to a person who has worked for $h$ years, is a years old at marriage; this person's age at pension claiming is $h+a$. Recall that $\rho(h+a)$ is about two-thirds for the average wage earner, as soon as an individual has crossed the retirement age, zero before that. $A$ represents any joint assets.

The key feature of the budget constraint is the pension replacement rate (PRR), $\rho_{i}\left(h_{i}+a_{i}\right)$. Let $R_{i}$ be the FRA. The PRR is zero before $R_{i}$, increases in an actuarially fair fashion between the full and the late retirement age $\left(R_{i}+5\right)$, and it stays constant thereafter. In our discussion here, we assume that the PRR is zero before the retirement age, jumps to a positive level and stays constant 
thereafter, i.e. $\rho_{i}\left(h_{i}+a_{i}\right)=0$ if $h_{i}+a_{i}<R_{i}$ and $\rho_{i}\left(h_{i}+a_{i}\right)=\rho$ if $h_{i}+a_{i} \geq R_{i}$. This simplification is not correct, but it captures the empirical regularity that fewer than $1 \%$ of all individuals claim pension benefits after the FRA (Lalive and Staubli, 2014).

Maximizing (1) subject to the budget constraint (2) produces the following first order condition for the husband:

$$
\frac{L_{M}^{\lambda-1}}{\frac{1}{\theta_{M}} L_{F}^{\frac{\lambda}{\theta_{M}}-1}}=\frac{w_{M}-w_{M} \rho\left(h_{M}+a_{M}\right)}{w_{F}-w_{F} \rho\left(h_{F}+a_{F}\right)}
$$

The female spouse also maximizes (1) subject to the budget constraint (2) and her optimal leisure choices are characterized by the following condition.

$$
\frac{L_{F}^{\lambda-1}}{\frac{1}{\theta_{F}} L_{M}^{\frac{\lambda}{\theta_{F}}-1}}=\frac{w_{F}-w_{F} \rho\left(h_{F}+a_{F}\right)}{w_{M}-w_{M} \rho\left(h_{M}+a_{M}\right)}
$$

Optimal duration of retirement, in logs, from the point of view of the husband is:

$$
\ln L_{M}=\frac{1}{1-\lambda}\left[\ln \theta_{M}+\ln \left(\frac{\tilde{w}_{F}}{\tilde{w}_{M}}\right)+\left(1-\frac{\lambda}{\theta_{M}}\right) \ln L_{F}\right]
$$

where $\tilde{w}_{F}$ and $\tilde{w}_{M}$ are the numerator and denominator in right hand side of equation (3), respectively, and $\lambda$ is positive but smaller than 1 according to Merkurieva (2011). Here we see that desired leisure of the husband depends on desired leisure of the wife to an extent that depends on how important the husband assesses the wife's leisure, $\theta_{M}$. If $\theta_{M}=1$, then the husband will increase leisure one for one with his wife's leisure. If $\theta_{M}<1$, the increase will be more than one-for-one. If $\theta_{M}>1$, the increase will be less than one for one.

The desired leisure combinations from the wife's point of view are the following:

$$
\ln L_{F}=\frac{1}{1-\lambda}\left[\ln \theta_{F}+\ln \left(\frac{\tilde{w}_{M}}{\tilde{w}_{F}}\right)+\left(1-\frac{\lambda}{\theta_{F}}\right) \ln L_{M}\right]
$$

It is obtained just replacing variables referring to the husband $M$ with those refering to the wife $F$ and vice versa.

We now solve for the wife's retirement by combining equations (5) and (6). By doing so, we solve for optimal retirement consistent with the point of view of both partners. This constitutes an equilibrium since no partner has an incentive to deviate. The equilibrium solution for the wife is: 


$$
\ln L_{F}=\frac{(1-\lambda) \ln \theta_{F}+\left(1-\frac{\lambda}{\theta_{F}}\right)-\left(\lambda-\frac{\lambda}{\theta_{F}}\right) \ln \frac{\tilde{w}_{M}}{\tilde{w}_{F}}}{(1-\lambda)^{2}-\left(1-\frac{\lambda}{\theta_{F}}\right)\left(1-\frac{\lambda}{\theta_{M}}\right)}
$$

Equation (7) shows that both labor supply incentives of the husband and his or her spouse matter for the wife's labor supply decision. ${ }^{5}$ The change in the pension replacement rate at the full age, captured by $\tilde{w}_{M}$ and $\tilde{w}_{F}$, affects the demand for leisure for both wife and husband. How much wives discount their husband's years of retirement in household well-being matters. Wives who discount their husband's leisure a lot, $\theta_{F}>1$, demand more leisure if their husband's net wage, $\tilde{w}_{M}$, increases relative to their own net wage, $\tilde{w}_{F}$, presumably because their husband works more. In contrast, wives who think their husband's retirement years are important for couple welfare will reduce their demand for leisure as the labor market opportunities of their partner improve.

\section{Data and Descriptive Analysis}

The analysis is based on data from the Swiss Federal Population Census covering the years 1990 and 2000. Census data include information on whether an individual is the head of household, a spouse, or a child, the number of people in the household, her age, education, mother language, labor market status, and religion, and further details about her place of work and residence.

We focus on a sample of married couples with the male partner in the age bracket of 50 to 80 years and the female partner in the age bracket 47 to 77 years. ${ }^{6}$ This sample ensures we observe an age range of 15 years before and 15 years after the FRA. The key outcome variable is labor force participation. The census allocates to the employed category all individuals who have worked at least one hour during the week of the census data collection (December 1990 or 2000). This category includes self-employed workers and individuals who are working in their family business without pay. Unemployed individuals are those who are out of a job but have been looking for a job within the previous four weeks. Labor force participants are those who are either employed or unemployed. We focus on labor force participation rather than on retirement because labor force participation (or nonparticipation) reflects all forms of inactivity. Thus, labor force participation also captures a transition from employment to non-employment in cases where people do not enter retirement right away.

The running variable in our regression discontinuity analysis is age. Census data contain information on age in years rather than in a continuous fashion. We account for this by clustering all our

\footnotetext{
${ }^{5}$ Extending our analysis to the case of the second spouse, we end up with a reduced form specification of her labor supply that is conceptually very similar to equation (7).

${ }^{6}$ We find no cohabitating couples in our estimation sample.
} 
analyses at the level of the individual's age and the partner's age, as recommended by Lee and Card (2008), using two-way clustering (Cameron, Gelbach and Miller, 2011).

\subsection{Descriptive Statistics}

Tables 1 and 2 report descriptive statistics for the women and men, respectively, in our sample. Columns 1-3 report the mean values and t-tests for the mean differences in the observable characteristics between individuals whose spouse exceeds the FRA (treated) and individuals whose spouse does not exceed the FRA (controls). Columns 4 and 5 present a test for balancing the co-variates at the retirement age thresholds (see below).

Our list of observables refers to the surveyed individuals' highest level of education achieved, languages spoken, and religious affiliation and the cantons where they lived. Tables 1 and 2 depict part of the Swiss population over the 1990-2000 period, revealing that the majority of people hold a secondary education, speak German, French or Italian as their mother tongues and are members of the Evangelical Reformed or Roman Catholic Church.

Table 1 about here

Column 4 in Tables 1 and 2 shows whether the observed characteristics are balanced at the age threshold at which the spouse is eligible for retirement. This column compares the mean of each characteristic for individuals whose spouse has just reached the FRA to the mean that would be expected from individuals whose partner had not yet reached the FRA. ${ }^{7}$

Column (4) therefore tests whether there are differences in the mean of covariates between women whose partner has reached the FRA and to women whose partner has not yet reached it, a key test of the validity of the RDD (Hahn et al. 2001; Lee and Lemieux, 2010). Notably, many of the significant differences between the treated and control women in column 3 disappear at the threshold. The only remaining significant differences for women refer to the proportion of French speakers $(0.75$ percentage points higher), the proportion of those living in Vaud (0.48 percentage points higher), and the proportion of immigrants (1.6 percentage points lower).

Table 2 about here

\footnotetext{
${ }^{7}$ Specifically, column 4 reports the point estimate of $\gamma$ in the following regression: $x_{i}=\alpha+\gamma D_{j}+\beta_{01}\left(S_{j}-R_{j}\right)+\beta_{02}\left(S_{j}-R_{j}\right)^{2}+\beta_{11} D_{j}\left(S_{j}-R_{j}\right)+\beta_{12} D_{j}\left(S_{j}-R_{j}\right)^{2}+\epsilon_{i}$

where $S_{j}$ is the age of the spouse, $R_{j}$ is the FRA of the spouse, and $D_{j}=1$ if $S_{j} \geq R_{j}$, and zero otherwise. Column 5 reports the standard error on $\gamma$.
} 
For men, we find that the proportion of Jews (0.06 percentage points higher) is not balanced (see Table 2 Column 4). However, while the number of non-balanced characteristics is somewhat larger than one would expect from mere chance, these imbalances are not quantitatively important to an extent that could bias results. In addition, the imbalances for both women and men refer to a piece of information we will control for. We conclude from this analysis that key background characteristics are balanced between individuals whose partner is eligible and individuals whose partner is not eligible. This is a key requirement for the RDD in partner age to be valid.

\subsection{Descriptive Evidence}

We are interested, first, in understanding how pension eligibility rules affect the labor supply patterns of individuals around the retirement age. Figures 1 and 2 show how an individual's labor supply varies with respect to her/his age. Figure 1 illustrates how women's labor force participation evolves with their own age. Labor force participation strongly decreases from approximately $68 \%$ at age 47 years to approximately $35 \%$ at age 61 years. Notably, labor force participation drops sharply between 61 and 62 years. Fewer than $20 \%$ of women age 62 years work or are currently looking for work, whereas the corresponding share is approximately $35 \%$ for women who are 61 years old. This sharp drop can plausibly be attributed to women reaching the FRA and thereby gaining access to pension payments. Labor force participation rapidly decreases thereafter and reaches a level of approximately $5 \%$ or less at age 70 and above. ${ }^{8}$

Figure 1 about here

Notably, retirement decisions display sharp discontinuities at the FRA. This pattern of evidence cannot be rationalized in a life cycle labor supply with full access to financial markets. However, the pattern is in line with the fact that labor contracts in some industries end at the FRA. Behaghel and Blau (2012) argue that loss aversion also triggers early retirement in the U.S. We expect a similar reasoning to apply in Switzerland. Access to loans is less than fully developed.

Figure 2 displays the labor supply near retirement age for men. Strikingly, almost $100 \%$ of all men in the age bracket of 50 to 59 years report being employed or looking for work. Labor supply nonetheless decreases rapidly from 60 to 64 years, reaching a level of $60 \%$ at age 64 years. Labor supply again falls substantially for men who gain access to old-age pensions. Only approximately one in five men aged 65 years reports still being part of the labor force, whereas the corresponding

\footnotetext{
${ }^{8}$ Note that the labor supply of women near the FRA increased substantially over the 1990 to 2000 period (not shown in the figure). Whereas $60 \%$ of 47-year-old women worked in 1990, almost $75 \%$ of 47 -year-old women worked in 2000.
} 
figure is three out of five of the men aged 64 years. Men reduce their labor supply upon reaching the retirement age much more than women do because fewer women still work close to the retirement age, and retirement pensions are a smaller part of pension wealth for women than for men. Labor supply rapidly decreases with age to reach a level of $5 \%$ or less by age 75 years. ${ }^{9}$

Figure 2 about here

Figure 3 reports the labor force participation of women as a function of the age of their spouse. The key idea is that we should observe a discontinuous change in the labor supply of women triggered by retirement access of their spouse if spousal pension eligibility matters. The figure displays that the labor supply of women falls rapidly as their spouse ages. This is predominantly because of the similarity in age of spouses. The figure also shows a relatively small but abrupt reduction in the labor supply of women whose spouse is 64 years old compared to women whose spouse is 65 years old. Whereas approximately $30 \%$ of all women in the former group are economically active, only $25 \%$ of the latter group are.

Figure 3 about here

To isolate the effect of the spouse reaching FRA, Figure 4 presents the residuals of a regression of women's labor force participation on a dummy taking the value 1 if the women have reached the FRA threshold and a quadratic in age on both sides of the threshold. This regression cleans the data from any effect of the spouse's age on labor force participation. The results in Figure 4 indeed indicate a sizeable drop in labor force participation of women exactly when their partner reaches the FRA. The residuals are approximately 2.5 percentage points lower for women whose spouse is 65 years old than for women whose spouse is 64 years old.

Figure 4 about here

Figure 5 discusses manipulation at the age threshold, a key concern of the RDD (Lee and Lemieux, 2010). While it is difficult to envision how individuals would manipulate their own age or the age of their partner in a stable partnership, manipulation might still be a concern if retirement affects marital stability.

Figure 5 about here

\footnotetext{
${ }^{9}$ Unlike for women, labor supply actually decreased between 1990 and 2000 for men. Whereas $70 \%$ of all men aged 64 years were still active in 1990, the corresponding figure had dropped to $50 \%$ in 2000.
} 
Figure 5 displays the number of women observed in partnerships with men aged 50 to 80 years. The results indicate that the number of women observed in a couple with men aged 63 to 69 years is somewhat higher than would be expected from a linear regression over the entire age range. However, the increase in the number of observations appears gradual and is by no means related to the age-65year threshold. We conclude based on evidence in Figure 5 that the manipulation of the age of the spouse (the running variable in the RDD) is not a concern.

Figure 6 about here

Figures 6 to 8 discuss effects of women's access to retirement on their husband's labor supply. Figure 6 shows that the labor force participation of men drops sharply as their wives become older, again mostly due to their own increasing age. There appears to be a discontinuous drop in labor force participation of men whose partner is 62 years old compared to men whose partner is 61 years old.

Figure 7 about here

Figure 7 reports the residuals of male labor force participation after dependence on their own age has been removed. ${ }^{10}$ Figure 7 indicates a reduction in male labor supply associated with wives' becoming eligible for an old-age pension, but the corresponding effect is a reduction of only approximately one percentage point, i.e., substantially smaller than the one for women. This substantially smaller reduction could be attributed to two reasons. First, women have a lower labor force participation than men once they obtain access to old-age pensions (Figure 1 vs Figure 2). Second, men coordinate their labor supply with their spouse less than women do.

Figure 8 about here

Figure 8 shows the possibility of manipulation at the threshold, revealing no substantial departure from a linear fit through the number of observations in the age bracket 52 years to 72 years.

\section{$5 \quad$ Empirical Strategy}

In our empirical approach we do not observe the number of years in retirement, $L$, but we have cross-sectional information on labor force participation. Inspired by a theoretical framework, we build models of whether an individual is in the labor force based on survey data. Our main estimation approach is the following double regression discontinuity (D-RDD) specification:

\footnotetext{
${ }^{10}$ We project the labor supply of men on a dummy indicating that the man has reached the FRA threshold and a quadratic polynomial in own age that is allowed to differ on either side of the threshold.
} 


$$
Y_{i}=\alpha+\gamma D_{i}+f_{i}\left(S_{i}-R_{i}\right)+\delta D_{j}+f_{j}\left(S_{j}-R_{j}\right)+\epsilon_{i j}
$$

where $Y_{i}=1$ if $i$ participates in the labor market, and $Y_{i}=0$ otherwise. ${ }^{11} S_{i}$ is $i$ 's age, $R_{i}$ is the FRA, and $D_{i}=I\left(S_{i} \geq R_{i}\right)$ is the pension eligibility indicator. The unknown functions $f_{i}(\cdot)$ and $f_{j}(\cdot)$ describe how labor force participation evolves with individuals' own age and their partner's age, relative to their own and their partner's FRA. ${ }^{12}$ Unlike a standard RDD, this model includes a full RDD specification for both partners in a couple.

Our specification is directly inspired from the theoretical framework we outlined earlier. That framework makes clear that both partners' pension eligibility matters for their optimal labor market exit age. The two key parameters of interest are $\gamma$ and $\delta . \gamma$ measures how one's own pension eligibility affects her decision to leave the labor force. $\delta$ measures how one's partner's pension eligibility affects her own decision to leave at her partner's eligibility age.

Across countries and contexts, many people leave the labor force at the FRA (Gruber and Wise, 1999), a phenomenon related to bunching. A novel feature of our approach is to study bunching at the partner's retirement age. Bunching at the partner's retirement age can occur if an individual works longer than her partner's retirement age, but upon her partner's passing the retirement age, she wants to leave the labor force. Our conceptual framework, discussed in section 3, suggests that bunching may occur because both partners' incentives matter. Optimal joint leisure requires that partners in a couple be sensitive to all incentives facing the household.

We will contrast results that use the double RDD specification above with the following approach:

$$
Y_{i}=\alpha+\gamma D_{i}+f_{i}\left(S_{i}-R_{i}\right)+\epsilon_{i j}
$$

This approach models labor supply as a function of an individual's own pension access, ignoring the labor supply effects of the partner's pension access. We discuss below to what extent the simple specification (9) or the extended specification (8) can be used to assess the effects of pension reform.

\footnotetext{
${ }^{11}$ Our empirical model of couple labor supply bears some resemblance to peer-effect models. See Angrist (2014) for an overview specification of peer-effect models.

${ }^{12}$ We approximate $f_{i}(\cdot)$, and $f_{j}(\cdot)$ using polynomials and local linear regression (see below in the results section), and we test manipulation and balancing of covariates in the next section.
} 


\section{Results}

We start by presenting the results from the simple model (9). Table 3 reports the estimates for women (top panel) and men (bottom panel), relaxing functional form assumptions as we move from columns (1) to (4). Column (1) results are based on wide age brackets, 15 years on either side of the FRA, assuming linear trends in labor force participation around the retirement age. Column (2) keeps the age bracket but allows a quadratic trend in age. Column (3) adds control variables. Column (4) focuses on couples no more than 5 years away from the FRA, keeping controls and allowing quadratic trends. Column (4) reports the most flexible estimates.

[Table 3 about here]

The most flexible standard RDD estimates indicate that labor supply drops sharply at the retirement age (column 4 of Table 3 ). Women are 12.4 percentage points less likely to work upon reaching the FRA. Men are 28.3 percentage points less likely to work upon reaching the FRA. The effects of these individuals' own pension eligibility are sizeable and suggest a significant proportion of women and men time their labor force exit to coincide with reaching the FRA.

How do the results change if individuals' own pension and their partner's pension access are taken into account? Table 4 reports the estimates of our key empirical model, equation (1), column (1) adopting a linear specification of $f_{i}$ and $f_{j}$ on either side of the FRA. The results indicate that women whose spouse has reached the FRA is 5 percentage points less likely to participate in the labor market than women whose spouse has not yet reached the FRA (coefficient "spouse's pension eligibility"). Women who have reached the FRA are 22 percentage points less likely to be economically active (coefficient "own pension eligibility").

[Table 4 about here]

Columns (2) to (4) show the sensitivity of this baseline finding with respect to the functional form in the terms reflecting the deviation from the full retirement threshold. Column (2) adopts a quadratic specification on either side of the retirement threshold. The results are sensitive to functional form. Women whose partner has reached the FRA are less likely to participate in the labor market. The corresponding effect is a reduction of 2.5 percentage points, approximately half the size measured in column (1). Moreover, women who become eligible for retirement pensions reduce their labor supply by 15 percentage points, approximately two thirds the size predicted in column (1). The results in column (2) indicate that finding an appropriate functional form is important. Column (3) shows the 
sensitivity of the results to the inclusion of control variables. Adding those variables does not change estimates of the spouse's access to retirement pensions or the estimate concerning a woman's own access to a retirement pension. Column (4) reduces the age bracket substantially, to five years above and five years below the FRA. The results indicate a 2.3 percentage point reduction in the labor supply of women due to the pension access of their spouses. Women who reach retirement age reduce their labor supply by 12.5 percentage points.

Our first explorations into the functional form show that the results are fairly sensitive to the choice of the polynomial order but less so to the bandwidth. At present, we are not aware of how to choose the bandwidth in the double RDD. The choice of bandwidth is not standard in our setting because imposing a bandwidth on one spouse will also select the partner. Imbens and Kalyanaraman (2012) discuss the optimal bandwidth choice in the standard RDD, featuring only one running variable and one threshold. Figure 9 shows the local polynomial smoothed version of the data, using the ImbensKalyanaraman optimal bandwidth of 1.8 years. Women clearly reduce their labor force participation at their partner's FRA. ${ }^{13}$

Figure 9 about here

Table 4 shows the results for men in the bottom panel. Columns (1) to (4) illustrate that functional form choices in the double regression discontinuity design is very important. Column (1), with linear trends, no controls, and large age brackets, shows a strong effect of the spouse reaching the retirement age on men, a reduction of 6.7 percentage points. The effect of their own retirement age is also strong, a reduction in labor supply of 49 percentage points. With higher-order trends, controls, and a fiveyear age bracket on either side, the cross-effect of the spouse becomes small and is not significantly different from zero. Women's eligibility might affect men less because women have access to small pensions, and fewer women leave the labor force at the FRA. Men's eligibility to a pension reduces their labor supply by 28 percentage points, about double the effect of women's own effect, in the preferred specification (column 4).

Partners in a couple typically do not reach retirement at the same time. Does it matter whether a woman reaches the retirement age before her spouse does? Table 5 addresses this issue. Column (1) reports the baseline results for all couples. Column (2) shows the results for women who reach the retirement age before their spouse does (at most two years younger than their spouse). The results for the partner eligibility effect are very much in line with the baseline. However, individuals' own

\footnotetext{
${ }^{13}$ We have also explored methods developed in Calonico et al. (2014). These methods require continuous assignment variables, so they are not adapted to our discrete assignment variable.
} 
eligibility differs somewhat. Women who reach the retirement age before their partner does reduce their labor supply by 14 percentage points, 2 percentage points more than the average. Column (3) shows the results for women who reach the retirement age after their spouse does (at least four years younger). Women who reach the retirement age after their partner reduce their labor supply by 10 percentage points, or 2 percentage points less than the average. ${ }^{14}$

[Table 5 about here]

The results are similar for men. The partner eligibility effect is small and insignificant regardless of whether a man reaches retirement age before or after his wife. However, men who reach the retirement age before their spouse does reduce their labor supply by 30.6 percentage points, somewhat more than average, whereas men who reach retirement after their spouse does reduces their labor supply by 27 percentage points, or less than the average. These results indicate that the spouse who reaches the retirement age first reacts more strongly to pension eligibility than the trailing spouse.

Access to a retirement pension might matter for both individuals' own and their partner's eligibility effects. A woman who has access to a retirement pension but is still working may react more strongly when her spouse reaches retirement than a woman who has no access to a retirement pension. Table 6 , top panel, presents results that limit the sample to women who are very close to the retirement age. Column (1) reproduces the baseline results from Table 4, column (4). Column (2) shows the results for women who are approximately three years from retirement age, none of them eligible for a retirement pension. Having a pension-eligible spouse reduces labor supply by 4.4 percentage points, somewhat more than average. Column (3), based on women approximately one year before retirement, shows an effect of 2 percentage points (insignificant), and column (4) shows an effect of 2.4 percentage points (significant). The partner eligibility effect does not appear to depend on women's own access to a retirement pension for those who are close to the regular retirement age.

[Table 6 about here]

We might also ask whether the effect of becoming eligible for a retirement pension depends on the presence of a pension-eligible spouse. Column (5) in Table 6 measures the retirement access effect for women whose spouse is approximately three years from retirement age. Women who reach the retirement age reduce their labor supply by 14.6 percentage points when living with a partner who is close to but not yet eligible for retirement; this effect is slightly but insignificantly larger than the effect in column (1). Columns (6) and (7) report an own effect of 13 percentage points also for women

\footnotetext{
${ }^{14}$ We exclude couples who reach pension eligibility at the same time, with an age difference of three years.
} 
whose spouse is one year before or one year after retirement. The own incentive effect does not depend on the pension access of the spouse.

How do the incentive effects of men and their partners play out? The bottom panel of Table 6 reports the results, following the same layout as for women. Partner eligibility effects are imprecisely estimated and somewhat larger than at the baseline. The partner eligibility effect for men who are at the FRA or older is significantly different from zero, -1.5 percentage points. However, the partner eligibility effects are not sensitive to the pension access of the spouse. How about men's own incentive effects? The own incentive effect is very much in line with our baseline estimate, a reduction of 28 to 30 percentage points. The results for men are coherent with the results for women.

Table 7 explores the role of education, a proxy for earning potential. Column (1) reproduces baseline estimates. Columns (2) to (5) report women's labor supply results, grouped by whether the women have high or low education and whether their spouse has high or low education. High education refers to people with degrees at the upper-secondary or tertiary level, whereas low education refers to people with degrees at the primary or lower-secondary levels. Consider first the own eligibility effect. Pension eligibility reduces the labor supply of women with high education by 12 percent (column 2) or 10.9 percent (column 3). Pension access has a stronger effect on women with a low level of education; the reduction is 14.7 percentage points (column 5) or 11.2 percentage points (column 4). This pattern is consistent with replacement rates being larger for low educated individuals. Notably, the smallest point estimate is for highly educated women married to a person with low education. This is consistent with the cap - at $150 \%$ of the man's pension - that applies to couple pensions.

[Table 7 about here]

Consider now the cross-incentive effects on women. For the own incentive effects, the crossincentive effect is somewhat, but not significantly, stronger for women with a low educated spouse compared to women with a highly educated spouse. Notably, the partner incentive effect is stronger for homogamous couples, where both partners have either a high education or a low education, than for heterogeneous couples.

The bottom panel of Table 7 shows the results for men. Low educated men who obtain access to a retirement pension tend to leave the labor force at a rate of 35.2 percentage points (column 5), or 28.1 percentage points (column 4). The effect on highly educated men is on average somewhat weaker, a reduction in labor supply by 22.8 percentage points (column 2) or 30.3 percentage points (column 3 ). The pattern of own eligibility effects for men mirrors that for women. 
Consider now the partner incentive effects for men (Table 7 bottom). Notably, the cross-incentive effects are strongest for men who live with a woman with the same level of education. Men with high education reduce their labor force participation by 1.3 percentage points if their highly educated spouse obtains pension access (column 2). Men with low education will, not significantly, reduce their labor force participation by 1.6 percentage points as their low educated spouse enters pension age (column 5). The partner effect estimate is close to zero or even positive for mixed couples.

What do our analyses imply for pension reforms that change the FRA? Our results so far suggest that labor supply decisions around the FRA are interconnected. Assessments of pension reform need to take this into account. A simple way to take couple interactions into account is to model joint labor supply. Specifically, we estimate the following model:

$$
Y_{F}+Y_{M}=\alpha+\gamma D_{F}+f_{F}\left(S_{F}-R_{F}\right)+\delta D_{M}+f_{M}\left(S_{M}-R_{M}\right)+\epsilon_{F, M}
$$

This model follows the exact same specification as our baseline. However, the dependent variable is the combined labor force participation of both spouses in the couple, rather than just one partner in the couple. ${ }^{15}$ The parameter $\gamma$ captures the effect of women reaching the FRA on couples' labor supply. This effect arises for two reasons. A woman may decide to leave the labor force because she is becoming eligible for a pension, or her husband may leave the labor force because she becomes eligible for a pension. The parameter $\delta$ captures the effect of men reaching the FRA on couples' labor supply. This effect captures the effect of pension eligibility on the man's labor supply and on his wife's labor supply. ${ }^{16}$

[Table 8 about here]

Table 8 shows the results of our empirical exercises. The results indicate that the pension eligibility of the wife reduces a couple's labor supply by 13.5 points; almost all of this due to the wife's leaving the labor market. The pension eligibility of the husband reduces a couple's labor supply by 30.7 points; most of this is due to the effect on the husband, but some of it is also due to the effect on the wife.

Columns (2) to (5) explore the role of education. The pension eligibility of women reduces the

\footnotetext{
${ }^{15}$ The interpretation of the parameter estimates is slightly non-standard. The dependent variable takes a value of 0 if both partners in the couple have left the labor force, 1 if one partner works, and 2 if both partners work. We refer to the parameter estimate multiplied by one hundred as points, bearing in mind that these are not points out of 100 but points out of 200 .

${ }^{16}$ This specification allows any cross-partner correlations in the error terms of a couple.
} 
labor supply most strongly for couples with a low educated husband and wife. The effect of raising women's retirement age is smallest for mixed couples. Pension eligibility for men is most effective in low educated couples, lowering labor supply by 38.1 points, and least effective for highly educated couples, lowering labor supply by 25.5 points. Mixed couples respond to an intermediate extent.

Consider the effects of raising the FRA for men. RDD estimates can be used to simulate small changes in the assignment threshold (Lee and Lemieux, 2010). Raising the retirement age is exactly such a policy. We use our estimates of the reaching the retirement age to assess the effects of increasing the FRA by a small amount, e.g., one year. The results from Table 8 show that raising the FRA for women increases couples' labor supply by 13.5 points; it increases by 30.7 points when the FRA is raised for men and by 44.2 points when the FRA is raised for both men and women.

Our results allow partner eligibility effects in couple labor supply. A simpler, alternative approach to couple labor supply would model each partner's labor force participation with each partner's pension eligibility. The model in Table 3, reported earlier, adheres to this simpler, alternative approach. Standard estimates of the own eligibility effect can be used to predict couples' labor supply. Couples' labor supply will increase by 12.4 points if the FRA is increased for women or by 28.3 points if the FRA is increased for men (Table 3). Adding the two effects yields a total effect of 40.7 points notably, 3.5 points less than in the joint scenario. Accounting for partner eligibility effects in labor supply is important.

\section{Conclusions}

This paper discusses the effects of pension eligibility on couples' labor supply. Adopting a double discontinuity design for both partners in a couple, we find that both men and women react strongly to reaching the full retirement age. Upon reaching the full retirement age, men are 28 percent and women are 12 percent less likely to be in the labor force. Women react significantly and qualitatively strongly to access to retirement pensions in Switzerland. No corresponding effect is found for men whose spouse gains access to retirement pensions. Low educated men and women react strongest to becoming eligible for a pension. Spouses in homogamous couples, regardless of their education level, are most strongly affected by their partner's pension eligibility.

These results have important implications for policies aiming to increase the full retirement age. Our analysis suggests that changes to women's retirement age would not significantly affect their male spouses. In contrast, raising the retirement age for men would produce double dividends because this 
increase would spill over to their female spouses. This analysis therefore shows that a policy targeted to one partner in a couple may well also change the behavior of the other partner in the couple. Assessing a reform without taking partners into account misses a small but potentially important part of its labor supply effect. 


\section{References}

[1] An, M.Y., Christensen, B.J., Gupta, N.D., 2004. Multivariate mixed proportional hazard modelling of the joint retirement of married couples. Journal of Applied Econometrics, 19(6): 687-704.

[2] Angrist, J.D., 2014. The perils of peer effects. Labour Economics, 30, 98-108.

[3] Baker, M., 2002. The retirement behavior of married couples: evidence from the spouse's allowance. Journal of Human Resources, 37(1): 1-34.

[4] Behaghel, L., Blau, D., 2012. Framing Social Security Reform: Behavioral Responses to Changes in the Full Retirement Age. American Economic Journal: Economic Policy, 4(4): 41-67.

[5] Blau, D.M., 1998. Labor force dynamics of older married couples. Journal of Labor Economics, $16(3), 595-629$.

[6] Blau, D.M., Gilleskie, D.B., 2006. Health insurance and retirement of married couples. Journal of Applied Econometrics, 21(7), 935-953.

[7] Burtless, G., 1986. Social security, unanticipated benefit increases, and the timing of retirement. Review of Economic Studies, 53(5): 781-805.

[8] Cameron A. C., Gelbach J. B., Miller D. L. , 2011. Robust Inference With Multiway Clustering, Journal of Business and Economic Statistics, Vol. 29, Iss. 2, 2011

[9] Calonico, S., Cattaneo, M.D., Titiunik, R., 2014. Robust Nonparametric Confidence Intervals for RegressionDiscontinuity Designs. Econometrica, 82(6), 2295-2326.

[10] Casanova Rivas, C., 2010. Happy together: A structural model of couples' joint retirement decisions. Working paper, UCLA.

[11] Chiappori, P.A., 1988. Rational household labor supply. Econometrica: Journal of the Econometric Society, 63-90.

[12] Coile, C., 2004. Retirement Incentives and Couples' Retirement Decisions. Topics in Economic Analysis \& Policy, 4(1), 1277.

[13] French, E., 2005. The effects of health, wealth, and wages on labor supply and retirement behavior. Review of Economic Studies, 72(2): 395-427. 
[14] Gruber, J., Wise, D.A., 1999. Editors. Social Security and Retirement Around the World. Chicago: University of Chicago Press for NBER.

[15] Gustman, A.L., Steimeier, T.L., 1986. A structural retirement model. Econometrica, 54(3): 555584.

[16] Gustman, A.L., Steimeier, T.L., 2000. Retirement in dual career families. Journal of Labor Economics 18(3): 503-545.

[17] Gustman, A.L., Steinmeier, T.L., 2004. Social security, pensions and retirement behavior within the family. Journal of Applied Econometrics, 19(6): 723-737.

[18] Gustman, A.L., Steinmeier, T.L., 2005. The social security early entitlement age in a structural model of retirement and wealth. Journal of public Economics, 89(2): 441-463.

[19] Gustman, A., Steinmeier, T.L., 2009. Integrating retirement models. NBER Working Papers 15607. National Bureau of Economic Research, Inc.

[20] Hahn, J., Todd, P., Klaauw, van der, W., 2001. Identification and estimation of treatment effects with a regressiondiscontinuity design. Econometrica, 69(1), 201-209.

[21] Honoré, B., de Paula, A., 2010. Interdependent Durations. Review of Economic Studies, 77, 1138-1163.

[22] Hurd, M.D., 1990. The Joint Retirement Decision of Husbands and Wives. In: Issues in the Economics of Aging, Wise, D. A. (ed). University of Chicago Press, 231-258.

[23] Imbens, G.W., Kalyanaraman, K., 2012. Optimal bandwidth choice for the regression discontinuity estimator. Review of Economic Studies, 79: 933959.

[24] Jia, Z., 2005. Labor supply of retiring couples and heterogeneity in household decision-making structure. Review of Economics of the Household, 3(2), 215-233.

[25] Klaauw, van der, W., Wolpin, K., 2008. Social security and the retirement and savings behavior of low-income households. Journal of Econometrics 145 (1-2), 21-42.

[26] Koller, T., 1998. Ehescheidung und die AHV. Aktuelle Juristische Praxis (AJP) 3/98, 291-310.

[27] Lalive, R., Staubli, S., 2014. How does the full retirement age affect labor supply?. Mimeo, University of Lausanne. 
[28] Lee, D.S., Card, D., 2008. Regression discontinuity inference with specification error. Journal of Econometrics 142: 655-674.

[29] Lee, D.S., Lemieux, T., 2010. Regression Discontinuity Designs in Economics. Journal of Economic Literature, American Economic Association, 48(2), 281-355.

[30] Maestas, N., 2001. Labor, love \& leisure: complementarity and the timing of retirement by working couples. Unpublished manuscript; University of California, Berkeley.

[31] Mastrogiacomo, M. , Alessie, R., Lindeboom, M., 2002. Retirement behaviour of Dutch elderly households. Journal of Applied Econometrics, 19(6): 777-794.

[32] Merkurieva, I., 2011. Coordinating the Household Retirement Decision. University of WisconsinMadison.

[33] Michaud, P.C., 2003. Joint labour supply dynamics of older couples. IZA Discussion Paper No. 832.

[34] Michaud, P.C., Vermeulen, F., 2004. A collective retirement model: identification and estimation in the presence of externalities. IZA Discussion Paper No. 1294.

[35] OECD, 2011. Pensions at a glance 2011: Retirement-Income Systems in OECD Countries: Switzerland. Online Country Profiles, Paris.

[36] Rust, J., Phelan, C., 1997. How Social security and medicare affect retirement behavior in a world of incomplete markets. Econometrica, 65(4): 781-831.

[37] Stancanelli, E., Van Soest, A., 2012a. Retirement and Home Production: A Regression Discontinuity Approach. American Economic Review, American Economic Association, 102(3), 600-605.

[38] Stancanelli, E., Van Soest, A., 2012b. Joint Leisure Before and After Retirement: A Double Regression Discontinuity Approach. IZA Discussion Papers 6698, Institute for the Study of Labor (IZA).

[39] Stock, J.H., Wise, D.A., 1990. Pensions, the option value of work, and retirement. Econometrica, 58(5): $1151-80$.

[40] Zweimüller, J., Winter-Ebmer, R., Falkinger, J., 1996. Retirement of spouses and social security reform. European Economic Review, 40(2), 449-472. 
Figure 1: Women's labor market participation over their own age.

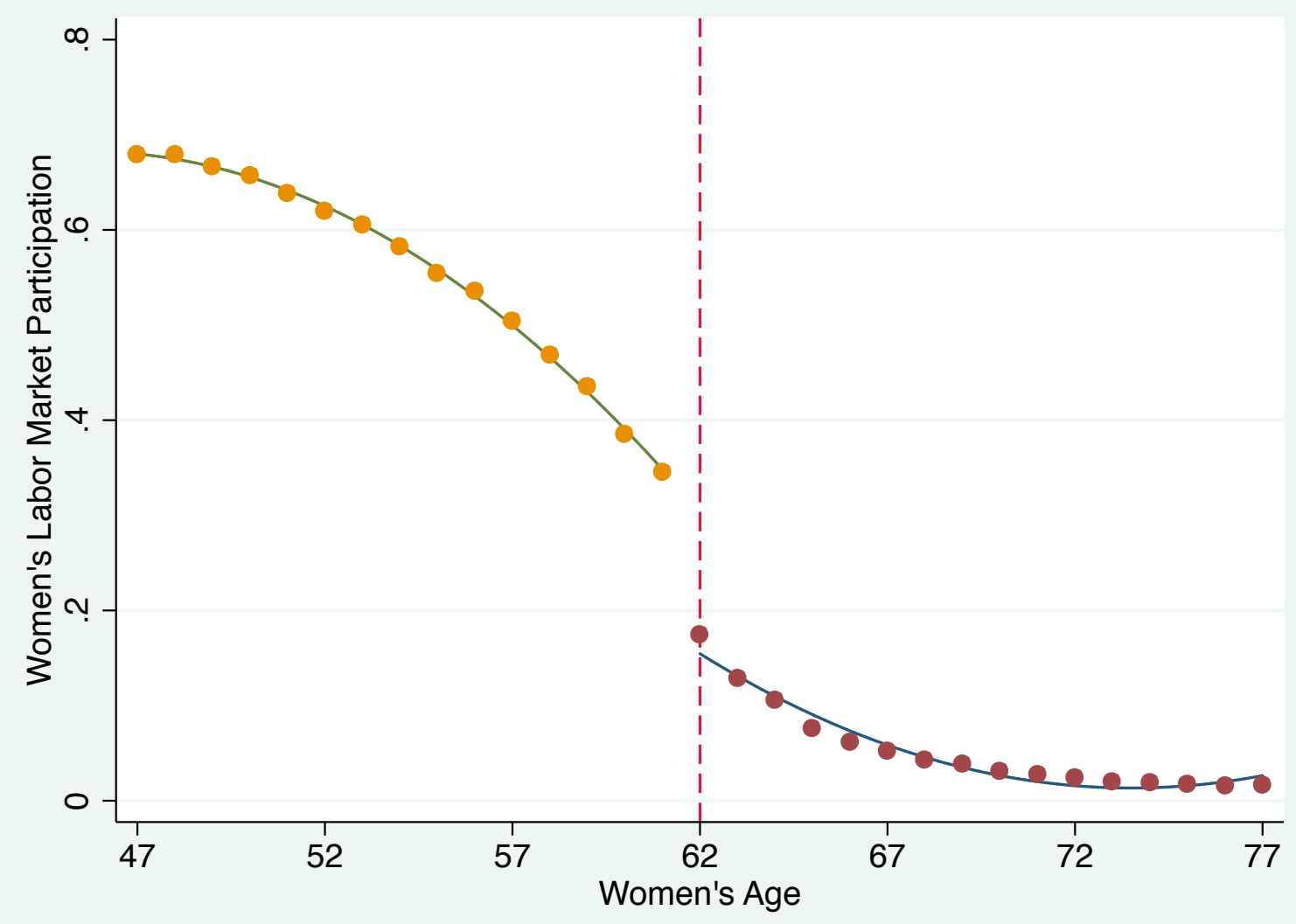

Source: Swiss Census data.

Legend: The dashed vertical line indicates the female full retirement age. 
Figure 2: Men's labor market participation over their own age.

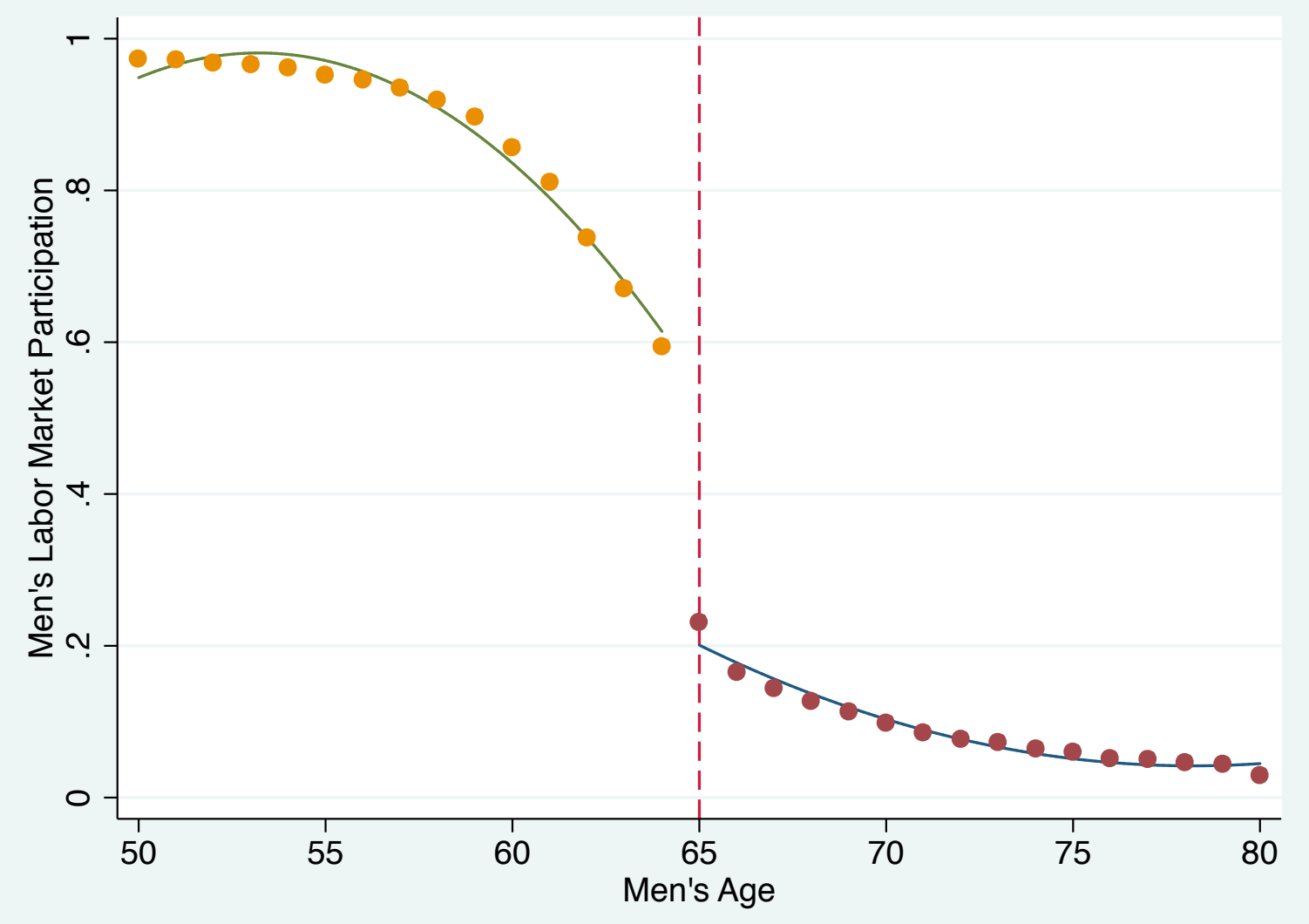

Source: Swiss Census data.

Legend: The dashed vertical line indicates the male full retirement age. 
Figure 3: Women's labor market participation over their spouses' age.

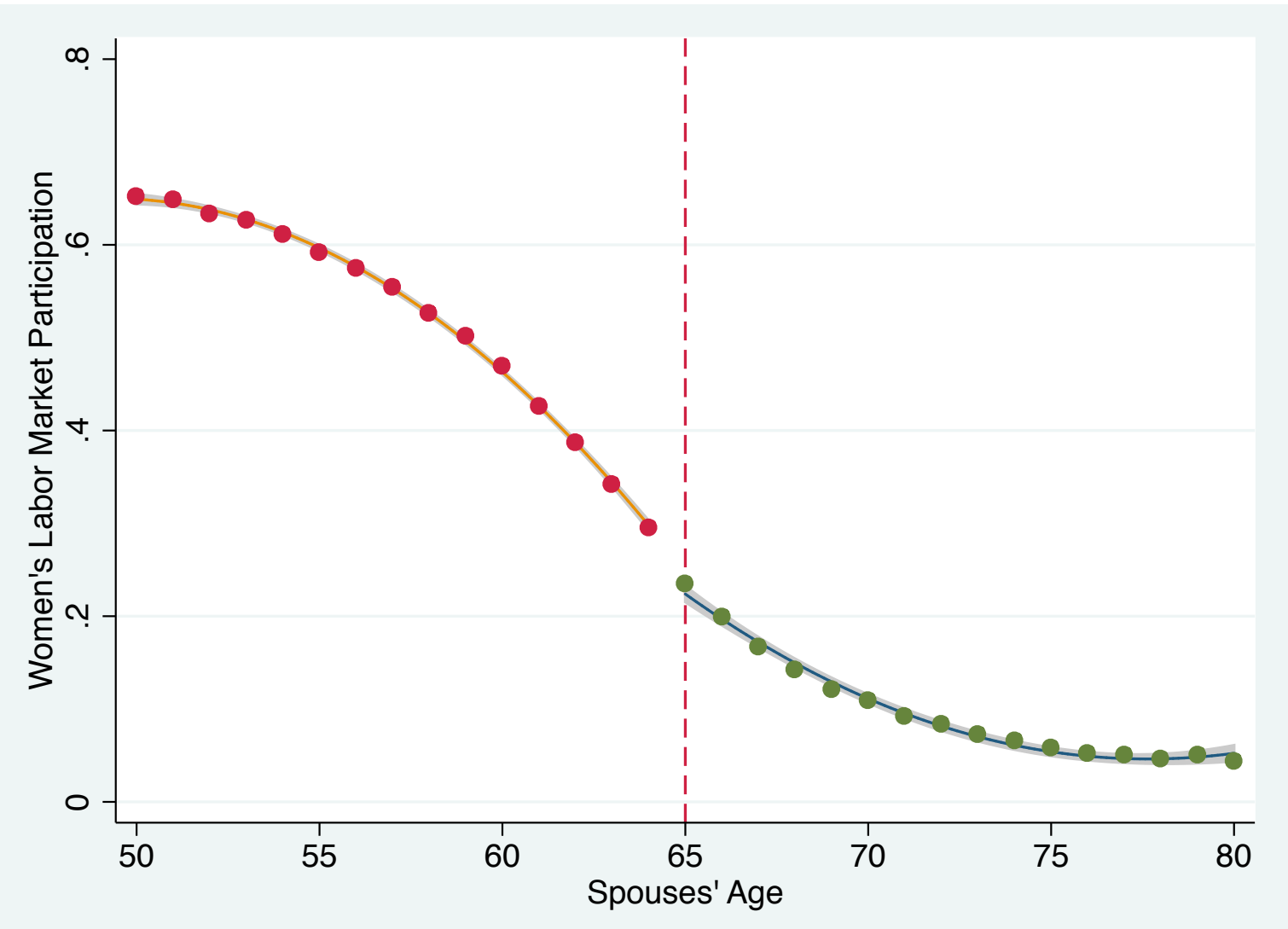

Source: Swiss Census data.

Legend: Quadratic fit, 95\% confidence interval and scatter plot. The dashed vertical line indicates the male full retirement age. 
Figure 4: Women: Residuals from a quadratic RDD on own full retirement age over their spouses' age.

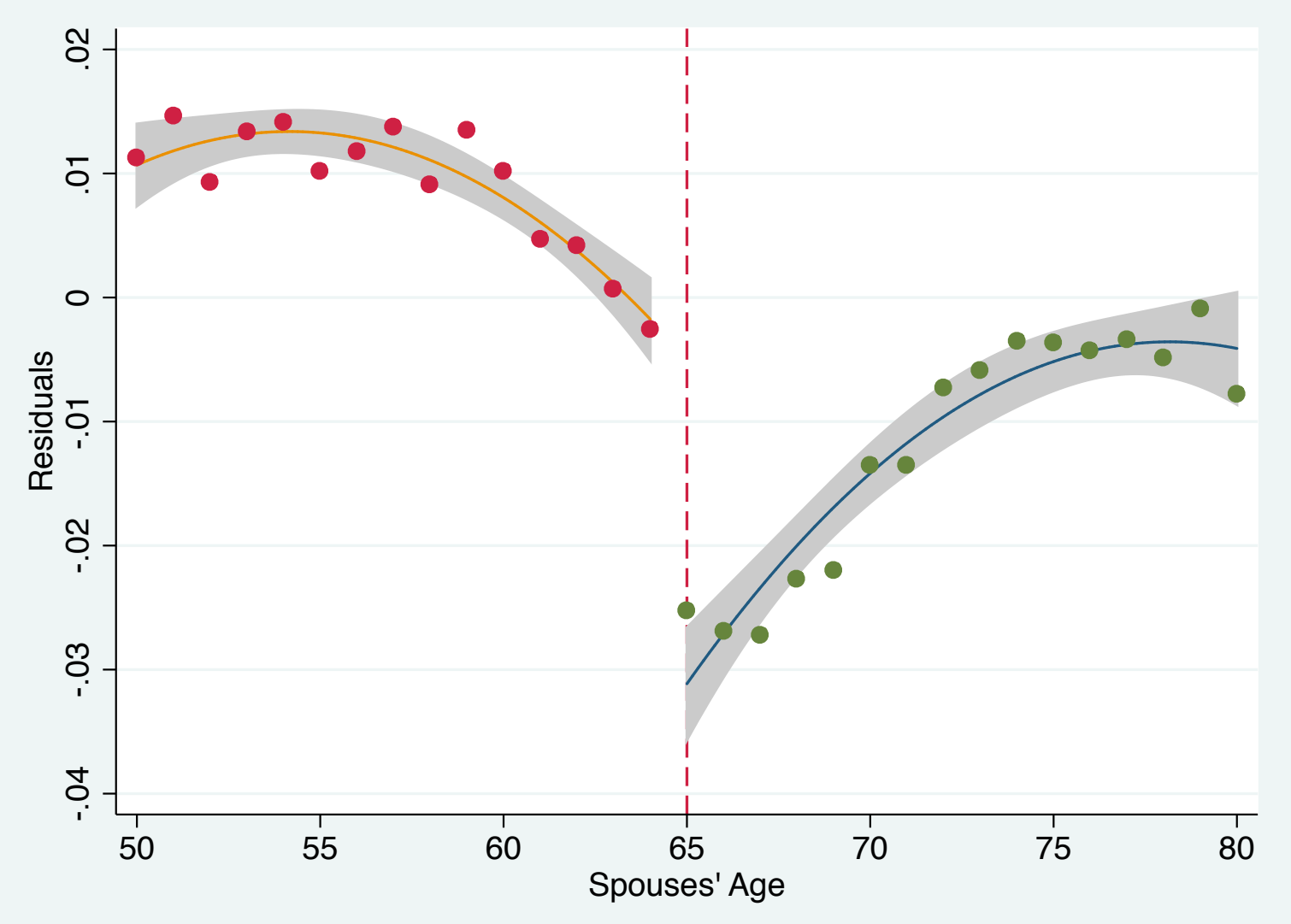

Source: Swiss Census data.

Legend: Quadratic fit, 95\% confidence interval and scatter plot. The dashed vertical line indicates the male full retirement age. 
Figure 5: Number of women over their spouses' age.

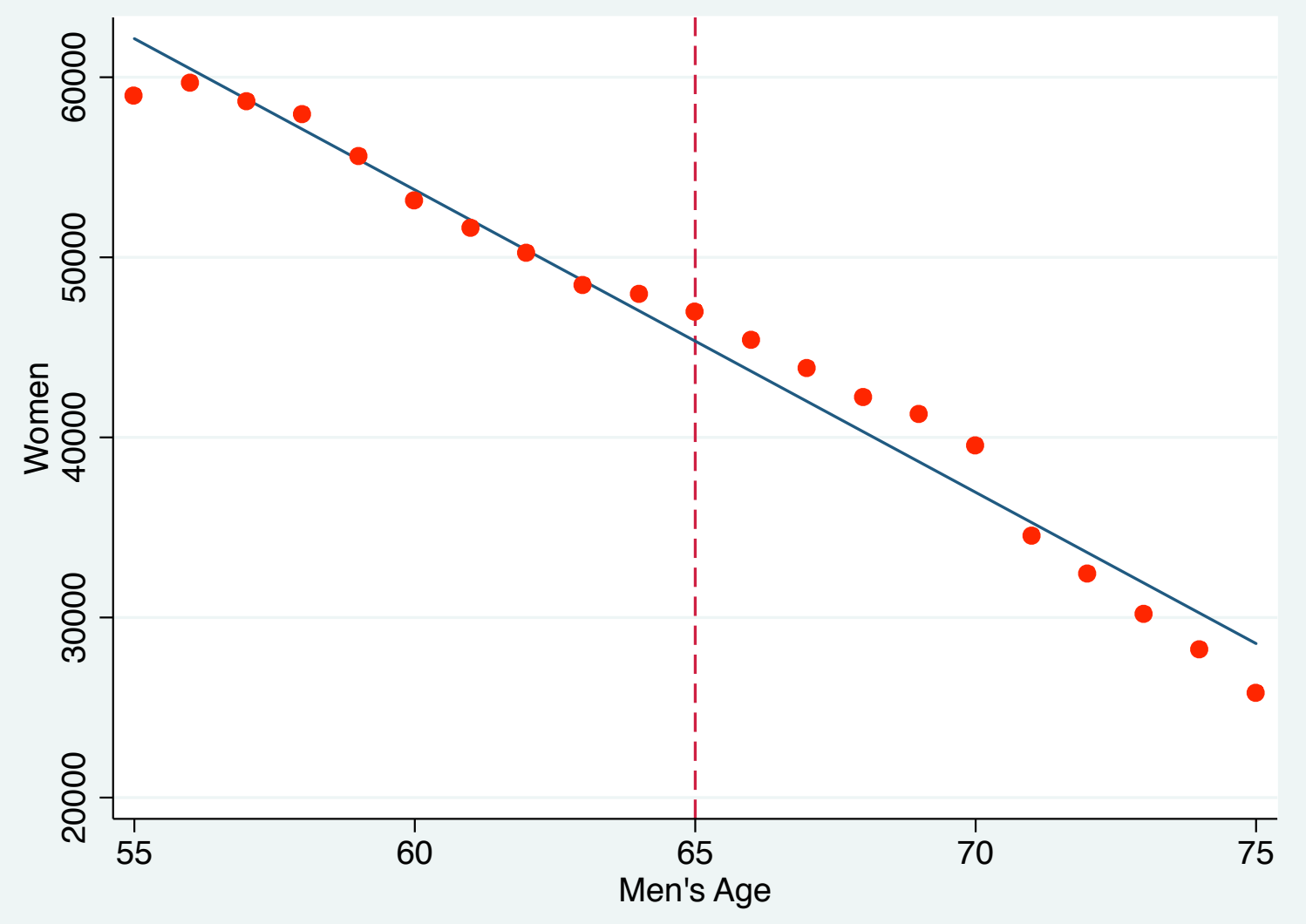

Source: Swiss Census data.

Legend: The dashed vertical line indicates the male full retirement age. 
Figure 6: Men's labor market participation over their spouses' age.

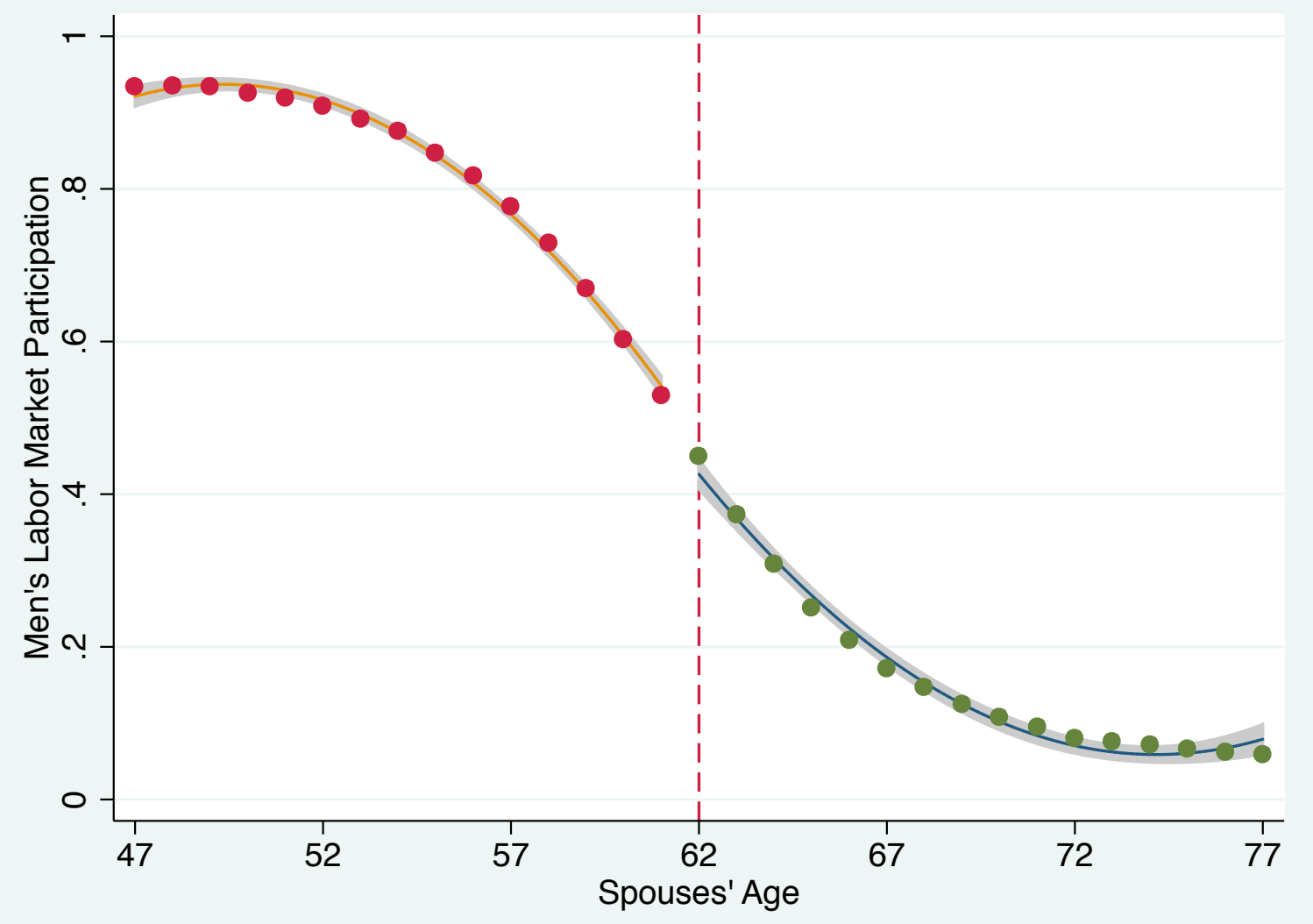

Source: Swiss Census data.

Legend: Quadratic fit, 95\% confidence interval and scatter plot. The dashed vertical line indicates the female full retirement age. 
Figure 7: Men: Residuals from a quadratic RDD on own full retirement age over their spouses' age.

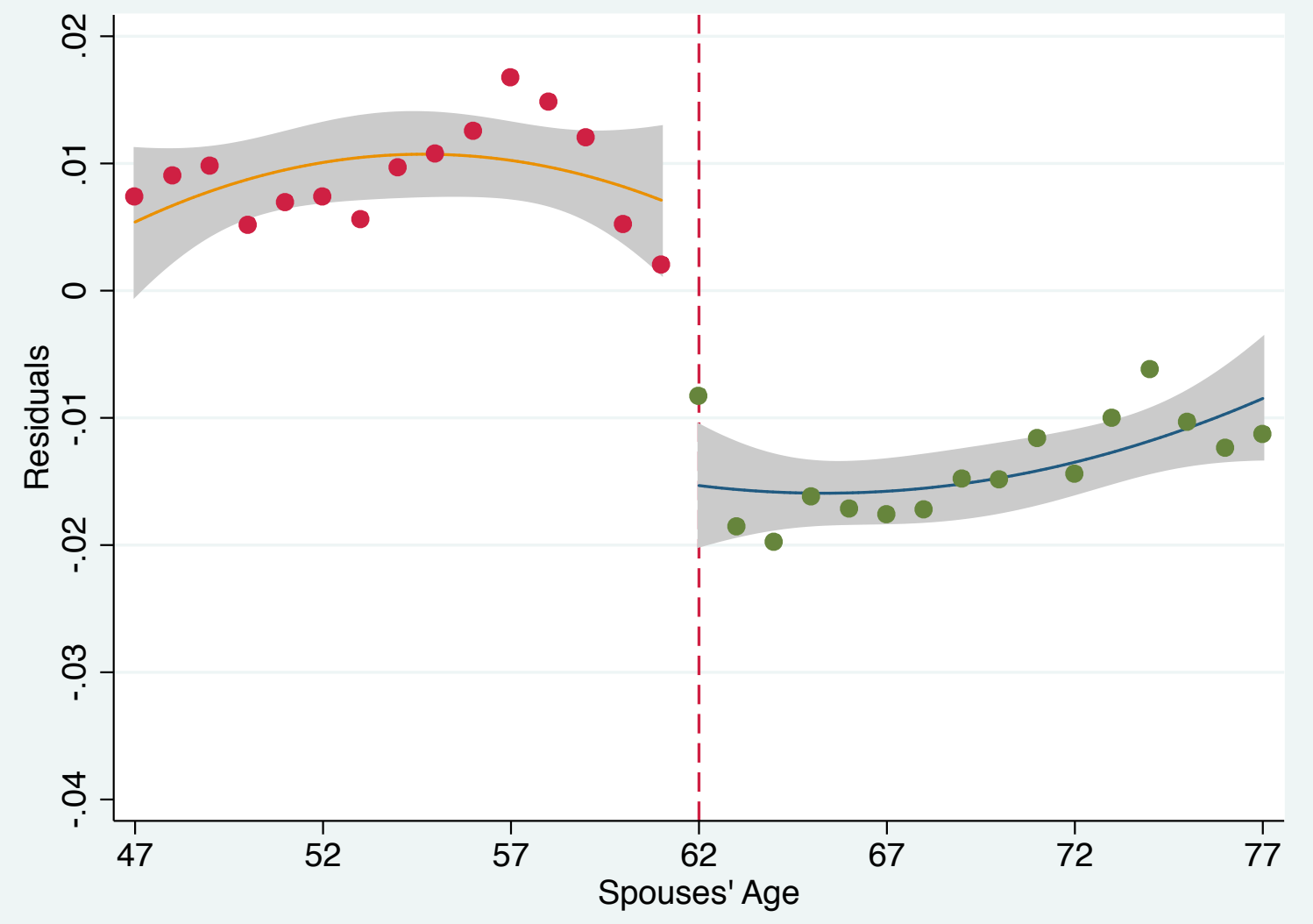

Source: Swiss Census data.

Legend: Quadratic fit, 95\% confidence interval and scatter plot. The dashed vertical line indicates the female full retirement age. 
Figure 8: Number of men over their spouses' age.

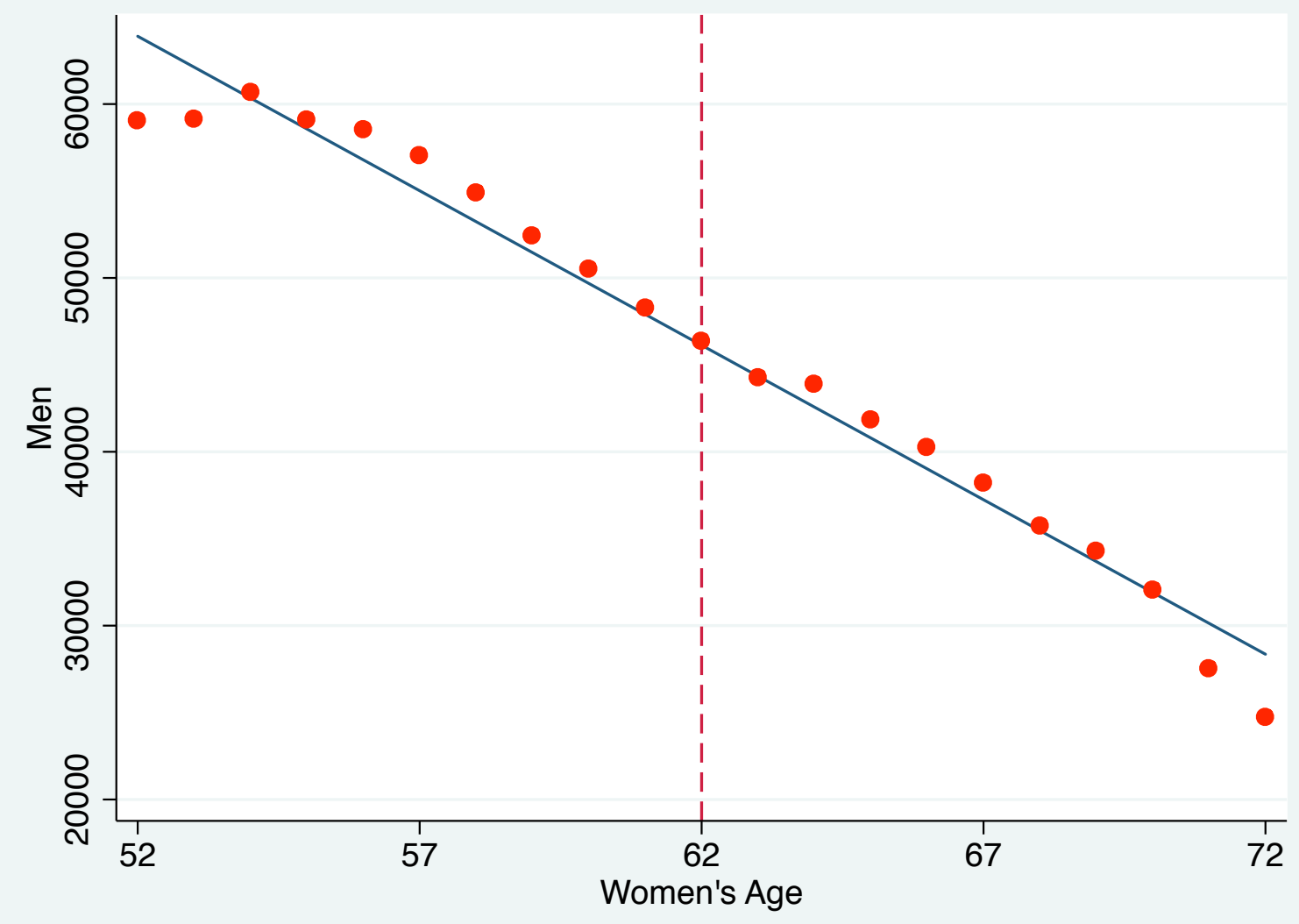

Source: Swiss Census data.

Legend: The dashed vertical line indicates the female full retirement age. 
Figure 9: Women: Local polynomial regression.

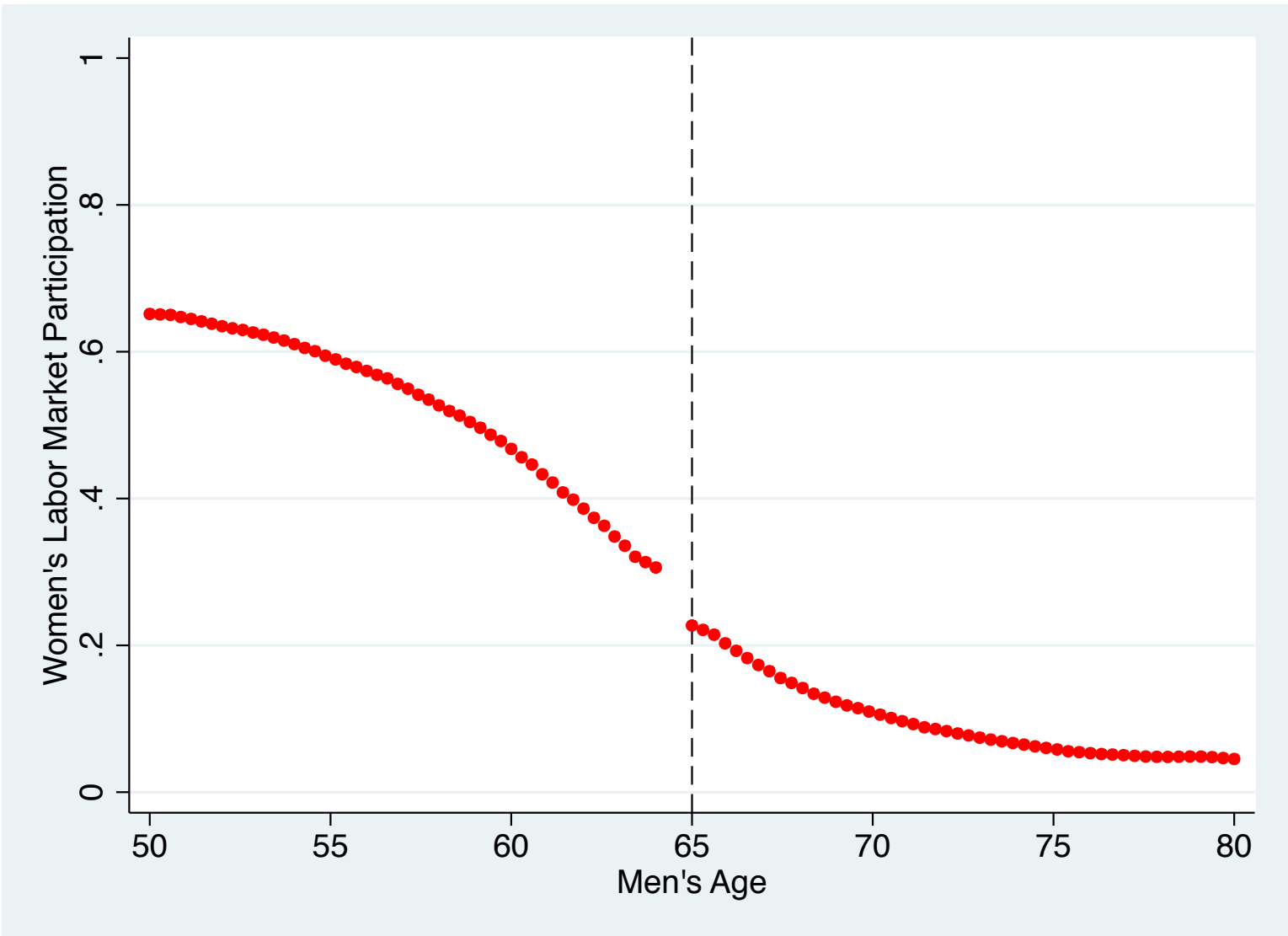

Source: Swiss Census data.

Legend: The dashed vertical line indicates the female full retirement age. We use an optimal confidence bandwidth (1.41) as suggested by Imbens and Kalyanaraman (2012). 
Table 1: Women - Descriptive Statistics

\begin{tabular}{|c|c|c|c|c|c|}
\hline \multirow[t]{2}{*}{ Spouse's Age } & \multirow{2}{*}{$\begin{array}{l}50-64 \\
\text { Mean } \\
\end{array}$} & \multicolumn{2}{|l|}{$65-80$} & \multicolumn{2}{|c|}{$50-80$} \\
\hline & & mean & difference & coefficient & std.error \\
\hline \multicolumn{6}{|l|}{ Education } \\
\hline Tertiary & 0.0690 & 0.0448 & $0.0242^{* * *}$ & -0.0016 & 0.0026 \\
\hline Secondary II & 0.4729 & 0.3760 & $0.0969^{* * *}$ & 0.0017 & 0.0085 \\
\hline Secondary I & 0.3926 & 0.4745 & $-0.0819 * * *$ & 0.0001 & 0.0074 \\
\hline Other & 0.0656 & 0.1047 & $-0.0391^{* * *}$ & -0.0002 & 0.0029 \\
\hline \multicolumn{6}{|l|}{ Language } \\
\hline German & 0.6544 & 0.7024 & $-0.0480 * * *$ & 0.0011 & 0.0066 \\
\hline French & 0.1820 & 0.1991 & $-0.0171^{* * *}$ & $0.0075^{* * *}$ & 0.0023 \\
\hline Italian & 0.0961 & 0.0681 & $0.0280^{* * *}$ & -0.0081 & 0.0059 \\
\hline Romansh & 0.0061 & 0.0071 & $-0.0010^{* * *}$ & 0.0007 & 0.0005 \\
\hline Other & 0.0615 & 0.0232 & $0.0383^{* * *}$ & -0.0012 & 0.0024 \\
\hline \multicolumn{6}{|l|}{ Religion } \\
\hline Evangelical Reformed Church & 0.3987 & 0.4671 & $-0.0684^{* * *}$ & 0.0074 & 0.0068 \\
\hline Roman Catholic Church & 0.4654 & 0.4252 & 0.0401 & -0.0058 & 0.0066 \\
\hline Jewish & 0.0023 & 0.0030 & $-0.0007^{* * *}$ & -0.0002 & 0.0002 \\
\hline Muslim & 0.0095 & 0.0025 & $0.0070^{* * *}$ & -0.0006 & 0.0008 \\
\hline Other & 0.1242 & 0.1023 & $0.0219^{* * *}$ & -0.0008 & 0.0023 \\
\hline \multicolumn{6}{|l|}{ Canton } \\
\hline Zurich & 0.4716 & 0.4832 & $-0.0116^{* * *}$ & -0.0015 & 0.0020 \\
\hline Vaud & 0.1743 & 0.1663 & $0.0080^{* * *}$ & $0.0048^{* * *}$ & 0.0004 \\
\hline Bern & 0.1392 & 0.1498 & $-0.0104^{* * *}$ & -0.0011 & 0.0021 \\
\hline Aargau & 0.0790 & 0.0702 & $0.0088^{* * *}$ & -0.0008 & 0.0011 \\
\hline Geneva & 0.0525 & 0.0465 & $0.0060^{* * *}$ & 0.0001 & 0.0016 \\
\hline Other & 0.0833 & 0.0840 & -0.0007 & -0.0015 & 0.0024 \\
\hline \multicolumn{6}{|l|}{ Wave } \\
\hline Year 2000 & 0.5367 & 0.5360 & 0.0007 & 0.0097 & 0.0089 \\
\hline \multicolumn{6}{|l|}{ Status } \\
\hline Immigrant & 0.1346 & 0.0561 & $0.0785^{* * *}$ & $-0.0159 * *$ & 0.0066 \\
\hline Own Age Bracket & $47-77$ & $47-77$ & & \multicolumn{2}{|c|}{$47-77$} \\
\hline Observations & 793,387 & 500,401 & & \multicolumn{2}{|c|}{$1,293,788$} \\
\hline
\end{tabular}

Notes: Mean values and t-test differences are reported. Coefficient and standard error are referred to the spouse's pension eligibility age (dummy variable) of our the quadratic RDD. Standard errors are clustered by own and spouse's deviation from pension elegibility age. Significance levels: $* * * 1 \%, * * 5 \%, * 10 \%$. 
Table 2: Men - Descriptive Statistics

\begin{tabular}{|c|c|c|c|c|c|}
\hline \multirow[t]{2}{*}{ Spouse's Age } & \multirow{2}{*}{$\frac{47-61}{\text { Mean }}$} & \multicolumn{2}{|l|}{$62-77$} & \multicolumn{2}{|c|}{$47-77$} \\
\hline & & mean & difference & coefficient & std.error \\
\hline \multicolumn{6}{|l|}{ Education } \\
\hline Tertiary & 0.2517 & 0.1907 & $0.0610^{* * *}$ & -0.0025 & 0.0066 \\
\hline Secondary II & 0.4950 & 0.4620 & $0.0330 * * *$ & -0.0013 & 0.0040 \\
\hline Secondary I & 0.2020 & 0.2610 & $-0.0590^{* * *}$ & 0.0017 & 0.0081 \\
\hline Other & 0.0513 & 0.0863 & $-0.0350^{* * *}$ & 0.0021 & 0.0020 \\
\hline \multicolumn{6}{|l|}{ Language } \\
\hline German & 0.6523 & 0.7073 & $-0.0550 * * *$ & -0.0018 & 0.0052 \\
\hline French & 0.1809 & 0.1980 & $-0.0171^{* * *}$ & -0.0030 & 0.0028 \\
\hline Italian & 0.1072 & 0.0683 & $0.0389 * * *$ & 0.0053 & 0.0046 \\
\hline Romansh & 0.0065 & 0.0071 & $-0.0006^{* * *}$ & -0.0003 & 0.0004 \\
\hline Other & 0.0530 & 0.0193 & $0.0337^{* * *}$ & -0.0001 & 0.0018 \\
\hline \multicolumn{6}{|l|}{ Religion } \\
\hline Evangelical Reformed Church & 0.3945 & 0.4785 & $-0.0840 * * *$ & 0.0004 & 0.0069 \\
\hline Roman Catholic Church & 0.4523 & 0.4036 & $0.0487^{* * *}$ & 0.0031 & 0.0066 \\
\hline Jewish & 0.0028 & 0.0027 & 0.0001 & $0.0006^{*}$ & 0.0004 \\
\hline Muslim & 0.0109 & 0.0025 & $0.0084^{* * *}$ & -0.0013 & 0.0009 \\
\hline Other & 0.1395 & 0.1127 & $0.0268^{* * *}$ & -0.0028 & 0.0030 \\
\hline \multicolumn{6}{|l|}{ Canton } \\
\hline Zurich & 0.4756 & 0.4770 & -0.0014 & 0.0010 & 0.0017 \\
\hline Vaud & 0.1727 & 0.1690 & $0.0037^{* * *}$ & -0.0010 & 0.0014 \\
\hline Bern & 0.1382 & 0.1516 & $-0.0134^{* * *}$ & 0.0028 & 0.0027 \\
\hline Aargau & 0.0782 & 0.0717 & $0.0064^{* * *}$ & -0.0010 & 0.0010 \\
\hline Geneva & 0.0523 & 0.0468 & $0.0055^{* * *}$ & -0.0008 & 0.0012 \\
\hline Other & 0.0833 & 0.0841 & -0.0008 & -0.0009 & 0.0035 \\
\hline \multicolumn{6}{|l|}{ Wave } \\
\hline Year 2000 & 0.5360 & 0.5373 & -0.0013 & 0.0103 & 0.0095 \\
\hline \multicolumn{6}{|l|}{ Status } \\
\hline Immigrant & 0.1684 & 0.0774 & $0.0910^{* * *}$ & -0.0000 & 0.0058 \\
\hline Own Age Bracket & $50-80$ & $50-80$ & & \multicolumn{2}{|c|}{$50-80$} \\
\hline Observations & 796,264 & 497,524 & & \multicolumn{2}{|c|}{$1,293,788$} \\
\hline
\end{tabular}

Notes: Mean values and t-test differences are reported. Coefficient and standard error are referred to the spouse's pension eligibility age (dummy variable) of our quadratic RDD. Standard errors are clustered by own and spouse's deviation from pension elegibility age. Significance levels: $* * * 1 \%, * * 5 \%, * 10 \%$. 
Table 3: Simple RDD - Women (top panel) and men (bottom panel)

\begin{tabular}{lcccc}
\hline & $(1)$ & $(2)$ & $(3)$ & $(4)$ \\
\hline Own pension eligibility & $-0.2393^{* * *}$ & $-0.1473^{* * *}$ & $-0.1474^{* * *}$ & $-0.1239^{* * *}$ \\
& $(0.0234)$ & $(0.0075)$ & $(0.0078)$ & $(0.0034)$ \\
\hline Time & yes & yes & yes & yes \\
Controls & no & no & yes & yes \\
Polynomial order & 1 & 2 & 2 & 2 \\
Spouse's age bracket & $50-80$ & $50-80$ & $50-80$ & $60-70$ \\
Own age bracket & $47-77$ & $47-77$ & $47-77$ & $57-67$ \\
\hline Adj R-squared & 0.2856 & 0.2875 & 0.2995 & 0.1546 \\
Observations & $1,293,788$ & $1,293,788$ & $1,293,788$ & 351,537 \\
\hline \hline & $(1)$ & $(2)$ & $(3)$ & $(4)$ \\
\hline Own pension eligibility & $-0.5127^{* * *}$ & $-0.3383^{* * *}$ & $-0.3383^{* * *}$ & $-0.2832^{* * *}$ \\
& $(0.0437)$ & $(0.0205)$ & $(0.0206)$ & $(0.0067)$ \\
\hline Time & yes & yes & yes & yes \\
Controls & no & no & yes & yes \\
Polynomial order & 1 & 2 & 2 & 2 \\
Spouse's age bracket & $47-77$ & $47-77$ & $47-77$ & $57-67$ \\
Own age bracket & $50-80$ & $50-80$ & $50-80$ & $60-70$ \\
\hline Adj R-squared & 0.6147 & 0.6219 & 0.6271 & 0.3676 \\
Observations & $1,293,788$ & $1,293,788$ & $1,293,788$ & 351,537 \\
\hline
\end{tabular}

Notes: The dependent variable is the individual labor market participation. Variables of interest is own pension elegibility age. Specifications (3) - (6) include also own and spouse's education, mother tongue, religion, county, immigrant and wave dummies. Standard errors are clustered by own and spouse's deviation from pension elegibility age. Standard errors are reported in parentheses. Significance levels: ***1\%, **5\%, ${ }^{*} 10 \%$. 
Table 4: Main results - Women (top panel) and men (bottom panel)

\begin{tabular}{lcccc}
\hline & $(1)$ & $(2)$ & $(3)$ & $(4)$ \\
\hline Spouse's pension eligibility & $-0.0499^{* * *}$ & $-0.0247^{* * *}$ & $-0.0239^{* * *}$ & $-0.0231^{* * *}$ \\
Own pension eligibility & $(0.0065)$ & $(0.0037)$ & $(0.0035)$ & $(0.0046)$ \\
& $-0.2209^{* * *}$ & $-0.1467^{* * *}$ & $-0.1468^{* * *}$ & $-0.1245^{* * *}$ \\
& $(0.0196)$ & $(0.0090)$ & $(0.0090)$ & $(0.0063)$ \\
\hline Time & yes & yes & yes & yes \\
Controls & no & no & yes & yes \\
Polynomial order & 1 & 2 & 2 & 2 \\
Spouse's age bracket & $50-80$ & $50-80$ & $50-80$ & $60-70$ \\
Own age bracket & $47-77$ & $47-77$ & $47-77$ & $57-67$ \\
\hline Adj R-squared & 0.2878 & 0.2892 & 0.3011 & 0.1576 \\
Observations & $1,293,788$ & $1,293,788$ & $1,293,788$ & 351,537 \\
\hline \hline & $(1)$ & $(2)$ & $(3)$ & $(4)$ \\
\hline Spouse's pension eligibility & $-0.0671^{* * *}$ & $-0.0190^{* * *}$ & $-0.0188^{* * *}$ & -0.0100 \\
& $(0.0126)$ & $(0.0011)$ & $(0.0030)$ & $(0.0062)$ \\
Own pension eligibility & $-0.4902^{* * *}$ & $-0.3385^{* * *}$ & $-0.3385^{* * *}$ & $-0.2840^{* * *}$ \\
& $(0.0399)$ & $(0.0205)$ & $(0.0206)$ & $(0.0095)$ \\
\hline Time & yes & yes & yes & yes \\
Controls & no & no & yes & yes \\
Polynomial order & 1 & 2 & 2 & 2 \\
Spouse's age bracket & $47-77$ & $47-77$ & $47-77$ & $57-67$ \\
Own age bracket & $50-80$ & $50-80$ & $50-80$ & $60-70$ \\
\hline Adj R-squared & 0.6172 & 0.6234 & 0.6285 & 0.3690 \\
Observations & $1,293,788$ & $1,293,788$ & $1,293,788$ & 351,537 \\
\hline \hline
\end{tabular}

Notes: The dependent variable is the individual labor market participation. Variables of interest are the spouse's and own pension eligibility age. Specifications (3) and (4) include also own and spouse's education, mother tongue, religion, county, immigrant and wave dummies. Standard errors are clustered by own and spouse's deviation from pension eligibility age. Standard errors are reported in parentheses. Significance levels: ${ }^{* * *} 1 \%,{ }^{*} 5 \%,{ }^{*} 10 \%$. 
Table 5: Entitlement and Retirement Timing-Women (top panel) and men (bottom panel)

\begin{tabular}{lccc}
\hline & $(1)$ & $(2)$ & $(3)$ \\
\hline Spouse's pension eligibility & $-0.0231^{* * *}$ & $-0.0214^{* * *}$ & $-0.0301^{* * *}$ \\
Own pension eligibility & $(0.0046)$ & $(0.0038)$ & $(0.0097)$ \\
& $0.1245^{* * *}$ & $-0.1446^{* * *}$ & $-0.1088^{* * *}$ \\
& $(0.0063)$ & $(0.0146)$ & $(0.0079)$ \\
\hline Time & yes & yes & yes \\
Controls & yes & yes & yes \\
Polynomial order & 2 & 2 & 2 \\
Spouse's age bracket & $60-70$ & $60-70$ & $60-70$ \\
Own age bracket & $57-67$ & $57-67$ & $57-67$ \\
\hline Adj R-squared & 0.1576 & 0.1480 & 0.1378 \\
Observations & 351,537 & 168,455 & 133,066 \\
\hline \hline & $(1)$ & $(2)$ & $(3)$ \\
\hline Spouse's pension eligibility & -0.0100 & -0.0080 & -0.0141 \\
& $(0.0062)$ & $(0.0068)$ & $(0.0140)$ \\
Own pension eligibility & $-0.2840^{* * *}$ & $-0.3060^{* * *}$ & $-0.2712^{* * *}$ \\
& $(0.0095)$ & $(0.0123)$ & $(0.0135)$ \\
\hline Time & yes & yes & yes \\
Controls & yes & yes & yes \\
Polynomial order & 2 & 2 & 2 \\
Spouse's age bracket & $57-67$ & $57-67$ & $57-67$ \\
Own age bracket & $60-70$ & $60-70$ & $60-70$ \\
\hline Adj R-squared & 0.3690 & 0.3089 & 0.3426 \\
Observations & 351,537 & 133,066 & 168,455 \\
\hline \hline
\end{tabular}

Notes: The dependent variable is the individual labor market participation. Variables of interest are the spouse's and own pension eligibility age. Column (1) reports our baseline specifications. Specifications (2) refer to whether the individual is or was eligible for pension before her/his spouse is or was. Specifications (3) refer to whether the individual is or was eligible for pension after her/his spouse is or was. All specifications include also own and spouse's education, mother tongue, religion, county, immigrant and wave dummies. Standard errors are clustered by own and spouse's deviation from pension eligibility age. Standard errors are reported in parentheses. Significance levels: ***1\%, **5\%, ${ }^{*} 10 \%$. 
Table 6: Own and Partner Eligibility Effects - Women (top panel) and men (bottom panel)

\begin{tabular}{lccccccc}
\hline & $(1)$ & $(2)$ & $(3)$ & $(4)$ & $(5)$ & $(6)$ & $(7)$ \\
\hline Spouse's pension eligibility & $-0.0231^{* * *}$ & $-0.0435^{*}$ & -0.0196 & $-0.0244^{* * *}$ & - & - & - \\
& $(0.0046)$ & $(0.0232)$ & $(0.0152)$ & $(0.0031)$ & - & - & - \\
Own pension eligibility & $-0.1245^{* * *}$ & - & - & - & $-0.1464^{* * *}$ & $-0.1283^{* * *}$ & $-0.1314^{* * *}$ \\
& $(0.0063)$ & - & - & - & $(0.0053)$ & $(0.0133)$ & $(0.0053)$ \\
\hline Polynomial order & 2 & 2 & 2 & 2 & 2 & 2 & 2 \\
Spouse's age bracket & $60-70$ & $60-70$ & $60-70$ & $60-70$ & $61-62$ & $63-64$ & $65-66$ \\
Own age bracket & $57-67$ & $58-59$ & $60-61$ & $62-63$ & $57-67$ & $57-67$ & $57-67$ \\
\hline Adj R-squared & 0.1576 & 0.0511 & 0.0447 & 0.0273 & 0.1029 & 0.1225 & 0.1398 \\
Observations & 351,537 & 63,885 & 73,624 & 71,812 & 69,191 & 73,689 & 71,947 \\
\hline \hline & $(1)$ & $(2)$ & $(3)$ & $(4)$ & $(5)$ & $(6)$ & $(7)$ \\
\hline Spouse's pension eligibility & -0.0100 & -0.0293 & -0.0037 & $-0.0154^{* * *}$ & - & - & - \\
Own pension eligibility & $(0.0062)$ & $(0.0262)$ & $(0.0069)$ & $(0.0037)$ & - & - \\
& $-0.2840^{* * *}$ & - & - & - & $-0.3001^{* * *}$ & $-0.2809^{* * *}-0.2916^{* * *}$ \\
& $(0.0095)$ & - & - & - & $(0.0089)$ & $(0.0071)$ & $(0.0092)$ \\
\hline Polynomial order & 2 & 2 & 2 & 2 & 2 & 2 & $60-61$ \\
Spouse's age bracket & $57-67$ & $57-67$ & $57-67$ & $57-67$ & $58-59$ & $62-63$ \\
Own age bracket & $60-70$ & $61-62$ & $63-64$ & $65-66$ & $60-70$ & $60-70$ & $60-70$ \\
\hline Adj R-squared & 0.3690 & 0.0516 & 0.0445 & 0.0422 & 0.3093 & 0.3298 & 0.3299 \\
Observations & 351,537 & 183,082 & 168,455 & 69,191 & 63,885 & 73,624 & 71,812 \\
\hline \hline
\end{tabular}

Notes: The dependent variable is the individual labor market participation. Variables of interest are the spouse's and own pension eligibility age. Column (1) reports our baseline specifications. All specifications include the full set of controls. Specifications (2)-(4) refer to specific 1-year own age bracket either before, at or after own full retirement age. Specifications (5)-(7) refer to specific 1-year own age bracket either before, at or after own full retirement age. Standard errors are clustered by own and spouse's deviation from pension eligibility age. Standard errors are reported in parentheses. Significance levels: ***1\%,**5\%,*10\%. 
Table 7: Robustness checks on education - Women (top panel) and men (bottom panel)

\begin{tabular}{lccccc}
\hline & $(1)$ & $(2)$ & $(3)$ & $(4)$ & $(5)$ \\
\hline Spouse's pension eligibility & $-0.0231^{* * *}$ & $-0.0267^{* * *}$ & -0.0222 & -0.0130 & $-0.0284^{* * *}$ \\
& $(0.0046)$ & $(0.0061)$ & $(0.0203)$ & $(0.0087)$ & $(0.0085)$ \\
Own pension eligibility & $-0.1245^{* * *}$ & $-0.1197^{* * *}$ & $-0.1085^{* * *}$ & $-0.1122^{* * *}$ & $-0.1472^{* * *}$ \\
& $(0.0063)$ & $(0.0095)$ & $(0.0346)$ & $(0.0071)$ & $(0.0094)$ \\
\hline Spouse's education & all & high & low & high & low \\
Own education & all & high & high & low & low \\
Spouse's age bracket & $60-70$ & $60-70$ & $60-70$ & $60-70$ & $60-70$ \\
Own age bracket & $57-67$ & $57-67$ & $57-67$ & $57-67$ & $57-67$ \\
\hline Adj R-squared & 0.1576 & 0.1547 & 0.1744 & 0.1348 & 0.1693 \\
Observations & 351,537 & 149,369 & 14,242 & 95,977 & 91,949 \\
\hline \hline & $(1)$ & $(2)$ & $(3)$ & $(4)$ & $(5)$ \\
\hline Spouse's pension eligibility & -0.0100 & $-0.0129^{* *}$ & -0.0066 & 0.0274 & -0.0164 \\
& $(0.0062)$ & $(0.0062)$ & $(0.0066)$ & $(0.0174)$ & $(0.0114)$ \\
Own pension eligibility & $-0.2840^{* * *}$ & $-0.2283^{* * *}$ & $-0.3034^{* * *}$ & $-0.2810^{* * *}$ & $-0.3523^{* * *}$ \\
& $(0.0095)$ & $(0.0125)$ & $(0.0104)$ & $(0.0257)$ & $(0.0139)$ \\
\hline Spouse's education & all & high & low & high & low \\
Own education & all & high & high & low & low \\
Spouse's age bracket & $57-67$ & $57-67$ & $57-67$ & $57-67$ & $57-67$ \\
Own age bracket & $60-70$ & $60-70$ & $60-70$ & $60-70$ & $60-70$ \\
\hline Adj R-squared & 0.3690 & 0.3301 & 0.3881 & 0.3608 & 0.3984 \\
Observations & 351,537 & 149,369 & 95,977 & 14,242 & 91,949 \\
\hline \hline
\end{tabular}

Notes: The dependent variable is the individual labor market participation. Variables of interest are the spouse's and own pension eligibility age. Column (1) reports our baseline specifications. All specifications include a quadratic design and the full set of controls. Standard errors are clustered by own and spouse's deviation from pension eligibility age. Standard errors are reported in parentheses. Significance levels: ***1\%, **5\%, ${ }^{*} 10 \%$. 
Table 8: Joint analysis - Summing labor force participation of both spouses.

\begin{tabular}{lccccc}
\hline & $(1)$ & $(2)$ & $(3)$ & $(4)$ & $(5)$ \\
\hline Wife's pension eligibility & $-0.1346^{* * *}$ & $-0.1326^{* * *}$ & $-0.1188^{* * *}$ & $-0.0812^{* * *}$ & $-0.1636^{* * *}$ \\
Husband's pension eligibility & $(0.0094)$ & $(0.0126)$ & $(0.0119)$ & $(0.0202)$ & $(0.0147)$ \\
& $-0.3071^{* * *}$ & $-0.2550^{* * *}$ & $-0.3164^{* * *}$ & $-0.3032^{* * *}$ & $-0.3808^{* * *}$ \\
& $(0.0102)$ & $(0.0143)$ & $(0.0152)$ & $(0.0433)$ & $(0.0165)$ \\
\hline Wife's education & all & high & low & high & low \\
Husband's education & all & high & high & low & low \\
Wife's age bracket & $57-67$ & $57-67$ & $57-67$ & $57-67$ & $57-67$ \\
Husband's age bracket & $60-70$ & $60-70$ & $60-70$ & $60-70$ & $60-70$ \\
\hline Adj R-squared & 0.3216 & 0.2955 & 0.3242 & 0.3143 & 0.3482 \\
Observations & 351,537 & 149,369 & 95,977 & 14,242 & 91,949 \\
\hline \hline
\end{tabular}

Notes: The dependent variable is the sum of husband's and wife's labor market participation. Variables of interest are the wife's and husband's pension eligibility age. Column (1) reports our baseline specification. All specifications include a quadratic design and the full set of controls. Standard errors are clustered by own and spouse's deviation from pension eligibility age. Standard errors are reported in parentheses. Significance levels: $* * * 1 \%, * * 5 \%,{ }^{*} 10 \%$. 